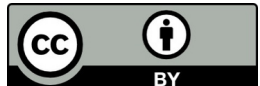

\title{
Evaluación de la respuesta inflamatoria e inmunológica en pacientes oncológicos bajo anestesia libre de opioides
}

Evaluation of the inflammatory and immunological response in cancer patients under opioid-free anesthesia

Avaliação da resposta inflamatória e imunológica em pacientes com câncer sob anestesia livre de opióides

\section{ARTÍCULO GENERAL}

\section{Yudelvis Caceres Ruiz \\ yudelviscaceresruiz@gmail.com \\ https://orcid.org/0000-0002-4978-0349}

Hospital Dr. Luis Razetti, Barinas - Venezuela

Recibido 07 de Junio 2021 | Arbitrado y aceptado 25 de Agosto 2021 | Publicado en 04 Diciembre 2021

\section{RESUMEN}

El cáncer está reconocido como un importante problema de salud pública debido a la alta frecuencia de casos y a su impacto económico, siendo una de las principales causas de morbilidad y mortalidad en el mundo, y la incidencia aumenta de forma exponencial con la edad gracias a la elevación de la expectativa de vida. (1) Por definición el paciente con cáncer es un paciente inmunodeprimido, donde el $90 \%$ de las muertes son debido a la progresión de la enfermedad, a las metástasis y no al tumor primario, gracias a la evolución natural de la enfermedad, que se puede ver acelerada por la inmunosupresión e inflamación sobreañadida tras procederes invasivos como cualquier acto quirúrgico gracias a que los mediadores propios de la inflamación tienen acciones angiogénicas, y con ello pueden crear el medio propicio para la recidiva tumoral. Por lo que el período perioperatorio es crítico en los desenlaces desde corto a largo plazo y en lo que respecta al acto anestésico, la naturaleza de la respuesta inflamatoria e inmune se produce por el daño tisular directo de la cirugía. (2) Sin embargo, la importancia para nosotros, los anestesiólogos, es que la anestesia puede modificarla. (3)

\section{ABSTRACT}

Cancer is recognized as an important public health problem due to the high frequency of cases and its economic impact, being one of the main causes of morbidity and mortality in the world, and the incidence increases exponentially with age thanks to the increase in life expectancy. (1) By definition, the cancer patient is an immunosuppressed patient, where $90 \%$ of deaths are due to disease progression, metastasis and not to the primary tumor, thanks to the natural evolution of the disease, which is It can be accelerated by immunosuppression and added inflammation after invasive procedures such as any surgical act, thanks to the fact that the mediators of inflammation have angiogenic actions, and thus can create the environment conducive to tumor recurrence. Therefore, the perioperative period is critical in short-term and long-term outcomes and in regard to the anesthetic act, the nature of the inflammatory and immune response is caused by direct tissue damage from surgery. (2) However, the importance for us anesthesiologists is that anesthesia can change it. (3)
\end{abstract}

\section{RESUMO}

O câncer é reconhecido como um importante problema de saúde pública devido à alta frequência de casos e seu impacto econômico, sendo uma das principais causas de morbidade e mortalidade no mundo, e a incidência aumenta exponencialmente com a idade graças ao aumento da expectativa de vida. (1) Por definição, o paciente oncológico é um paciente imunossuprimido, onde $90 \%$ das mortes se devem à progressão da doença, metástase e não ao tumor primário, graças à evolução natural da doença, que pode ser acelerada pela imunossupressão e inflamação adicional após procedimentos invasivos como qualquer ato cirúrgico, graças ao fato de que os mediadores da inflamação possuem ações angiogênicas, podendo assim criar o ambiente propício à recorrência tumoral. Portanto, o período perioperatório é crítico nos resultados a curto e longo prazo e em relação ao ato anestésico, a natureza da resposta inflamatória e imune é produzida pelo dano tecidual direto da cirurgia. (2) No entanto, a importância para nós, anestesiologistas, é que a anestesia pode modificá-la. (3) 


\section{INTRODUCCIÓN}

El cáncer está reconocido como un importante problema de salud pública debido a la alta frecuencia de casos y a su impacto económico, siendo una de las principales causas de morbilidad y mortalidad en el mundo, y la incidencia aumenta de forma exponencial con la edad gracias a la elevación de la expectativa de vida. (1) Por definición el paciente con cáncer es un paciente inmunodeprimido, donde el $90 \%$ de las muertes son debido a la progresión de la enfermedad, a las metástasis y no al tumor primario, gracias a la evolución natural de la enfermedad, que se puede ver acelerada por la inmunosupresión e inflamación sobreañadida tras procederes invasivos como cualquier acto quirúrgico gracias a que los mediadores propios de la inflamación tienen acciones angiogénicas, y con ello pueden crear el medio propicio para la recidiva tumoral. Por lo que el período perioperatorio es crítico en los desenlaces desde corto a largo plazo y en lo que respecta al acto anestésico, la naturaleza de la respuesta inflamatoria e inmune se produce por el daño tisular directo de la cirugía. (2) Sin embargo, la importancia para nosotros, los anestesiólogos, es que la anestesia puede modificarla. (3)

Ahora bien, partiendo del conocimiento que la anestesia general busca garantizar hipnosis, inmovilidad, analgesia y protección neurovegetativa; para permitir realizar cualquier procedimiento diagnóstico y/o terapéutico. (4) Aunado a ello tenemos también que la anestesia o la analgesia regional bloquean las aferencias nociceptivas intraoperatorias de forma pre-eventiva y disminuyen o eliminan el dolor agudo postoperatorio. $(4,5)$ Con ello al combinar la anestesia regional con la anestesia general, se disminuiría el consumo de varios fármacos anestésicos tales como los opioides y agentes inhalatorios, que son conocidos como inmunosupresores, siendo su uso visto de esta forma algo contradictorio si se quiere ofrecer a los pacientes oncológicos la anestesia adecuada, que les brinde la mejor modulación de la respuesta inflamatoria e inmune, buscando disminuir la respuesta neuroendocrina al estrés. Por ello, prevenir la inmunosupresión y la exagerada respuesta inflamatoria toma particular importancia, ya que esto permitiría detener o por lo menos retrasar el crecimiento tumoral y/o recidivas en este período de alto riesgo oncológico. $(6,7)$

Teniendo en cuenta datos epidemiológicos la OMS, en el 2010 el cáncer era la novena causa de muerte a nivel mundial y ya para el 2015 ocupaba el quinto lugar, con una cifra cercana a las 2 millones de defunciones anuales. Venezuela también reporta cifras elevadas. En el 2015, el Anuario de Mortalidad del año 2013, publicado en Gaceta 
Oficial No 40621 Decreto 1656 de fecha 16 de marzo de 2015, identifica al cáncer como la segunda causa de muerte con un $15.42 \%$ de todas las defunciones al año, y en Barinas también fue reportada como la segunda causa, teniendo en la entidad un valor de $12.51 \%$, principalmente causada por los tumores malignos de órganos digestivos.(8)

Conociendo todos estos elementos, y en relación al tipo de paciente quirúrgico que se aborda en este estudio, los anestesiólogos, aparte de ocuparse en ofrecer un plano anestésico seguro y eficaz que le propicie al cirujano un campo óptimo para la cirugía, deberían estar mejor preparados en prevenir o modular positivamente los efectos desordenados de la inflamación en el daño pulmonar, en la permeabilidad micro vascular, en el daño por reperfusión, en el dolor agudo y crónico y aún más, enfocarse en este paciente tipo oncológico donde se observa una inflamación crónica, e inmunodeprimido por definición. $(9,10)$ Sin embargo, en lo particular es visto el uso de la anestesia general inhalatoria y el uso de opioides como técnica tradicional, particularmente estándar, ya sea debido a bajos costos, o al desconocimiento de otras oportunidades que brinda la anestesia combinada, o comúnmente reconocida como multimodal: usando varios anestésicos endovenosos con diferentes mecanismos de acción, diferentes dianas en cuanto a receptores y de poco o ningún impacto negativo sobre la inflamación y el sistema inmune, y usar además técnicas regionales, todo ello resultaría en una poderosa herramienta que le daría mejores resultados a este tipo de paciente. $(11,12,13)$

En el servicio de anestesiología del Hospital Dr. Luis Razetti no hay existencia de protocolos estandarizados ni de probado impacto sobre la modulación de la respuesta inflamatoria e inmune para pacientes oncológicos y es por ello que se formula la siguiente pregunta de investigación:

¿La técnica anestésica multimodal endovenosa libre de opioides combinada con analgesia peridural propuesta por el autor, tiene impacto positivo en la modulación de la respuesta inflamatoria e inmune en pacientes oncológicos; si se estiman con la medición de los valores de proteína $\mathrm{C}$ reactiva e índice de neutrófilos/linfocitos respectivamente en el post-operatorio?

Por medio de la comparación de dos técnicas anestésicas: la convencional (Grupo A o Grupo Control: - anestesia inhalatoria con sevorane o isofluorane) vs técnica propuesta (anestesia multimodal endovenosa libre de opioides combinada con analgesia peridural (Grupo B o Grupo Experimental) se dio respuesta al problema de investigación, donde el propósito del estudio fue demostrar la atenuación de la respuesta inflamatoria y 
la mayor preservación de la integridad adaptativa del sistema inmune en los pacientes oncológicos anestesiados con la técnica propuesta, anestesia multimodal endovenosa libre de opioides combinada con analgesia peridural, en lo adelante AMELO.

De tal manera se justifica el estudio dada la importancia que tiene: teórica, científica, profesional, metodológica, social y económica ya que con los resultados obtenidos se permite integrar la teoría y los conocimientos que preceden con la demostrada relación causa-efecto del binomio anestesia-respuesta inflamatoria e inmune en un grupo de riesgo poblacional, y dónde el modelo social y sanitario de impacto a generar también es significativo. El valor científico no solo está dado por la significancia estadística de los resultados, también está reforzado por la significancia médica que se genera. En lo profesional se consigue un aporte más actual al acervo científico, acorde a los cambios de paradigmas que se espera en todo momento de un anestesiólogo que se preocupe y ocupe en brindarle a sus pacientes la mejor y más segura anestesia. También permite gestionar nuevos protocolos de manejo anestésico en estos pacientes oncológicos quirúrgicos.

Ahora bien, es necesario dar una cronología sobre la anestesia que permita entenderla como una variable independiente asociada al valor pronóstico de los pacientes con cáncer que necesitan una cirugía, además de exponer una serie de conceptos y teorías. Tenemos que el término de anestesia general balanceada fue utilizado por Lundy, en 1926, para describir la técnica de anestesia general brindada por un agente inhalado aunado a un agente endovenoso. Desde 1951, Woodbridge, describió los componentes de la anestesia y la combinación de fármacos y técnicas, cada una con un propósito primario y un efecto específico. Luego el uso de opioides se popularizó en la anestesia desde 1960, inicialmente usando grandes dosis de morfina y posteriormente, de fentanyl y otros opioides sintéticos, destacando la estabilidad hemodinámica que brindan. En ese entonces se estableció el paradigma de la anestesia basada en opioides, o conocida como anestesia basada en la analgesia. $(14,15)$ Y seguida la década de los 70, afortunadamente, David L. Bruce se interesó en el estudio de la cirugía y la respuesta inmune, en ese periodo fue posible entender que el estrés que origina la cirugía causa inmunodepresión, así mismo se observó que los anestésicos podían afectar la respuesta inmune. Ya en 1993 se introdujo la noción de la anestesia multimodal como «técnica ahorradora de opioides», la cual tenía por objetivo mejorar la analgesia mediante el empleo de fármacos con efectos 
sinérgicos o aditivos, mejorando no sólo la eficacia, sino también la seguridad del manejo analgésico. $(14,15)$

Finalmente se considera que la anestesia general libre o con poca cantidad de opioides surgió de la evidencia de que el uso de un adyuvante reduce los requerimientos de opioides durante y después de la cirugía, siendo entonces posible que la combinación de estos fármacos logre evitar todos los opioides en el transoperatorio y tener buen control del dolor sin el uso de ellos. También es de importancia conocer que existe evidencia experimental de que el control analgésico eficaz puede atenuar la inmunosupresión postoperatoria. La técnica libre de opioides ha sido utilizada con éxito desde el 2005 para el manejo de pacientes obesos sometidos a cirugía bariátrica. $(15,16,17)$

En otro orden de ideas, los criterios de calidad en la cirugía oncológica radical, se basan en la extirpación completa del tumor, con márgenes libres sin enfermedad macroscópica residual, en una linfadenectomía adecuada y en la mínima manipulación tumoral posible. Pero esto no siempre es lo que se consigue, pudiendo quedar células tumorales residuales, las que a su vez estarían luego sometidas a las condiciones de un sistema inmune deprimido incapaz de eliminarlas y a un medio con factores inflamatorios (citosinas proangiogénicas, factores de crecimiento, etc.) $(18,19)$

A causa del estímulo quirúrgico, se genera una reacción fisiológica, un estado caracterizado por la liberación de proteínas de fase aguda, hormonas de stress y citoquinas pro inflamatorias junto a una disminución en la respuesta inmunitaria celular manifestada por alteración en el reclutamiento, activación y función de los linfocitos circulantes y monocitos sumado a una disminución de su capacidad quimiotáctica, fagocítica y menor producción de anión superóxido. Todo ello conlleva una mayor propensión al desarrollo de complicaciones postoperatorias. El dolor en sí mismo suprime la inmunidad celular al inhibir la actividad de las células asesinas y favorece la progresión tumoral. $(20,21)$

Ante una agresión, el organismo responde con la inflamación para tratar de eliminar el agente agresor e iniciar la reparación de las estructuras dañadas; este proceso forma parte de la respuesta inmune innata, que si bien es inespecífica y no crea memoria, tiene una barrera humoral donde interviene el sistema complemento y la reacción inflamatoria y una barrera celular, los leucocitos polimorfonucleares que incluyen fagocitos (macrófagos, neutrófilos y células dendríticas), mastocitos, eosinófilos, basófilos y células asesinas. Luego, un sistema inmune intacto se defiende gracias a las células asesinas que son activadas por la IL-2 y el interferón gamma (IFN- $\gamma$ ). La cirugía 
también incrementa las concentraciones de factores proangiogénicos e inhibe la actividad de las células asesinas, citoquinas que favorecen la inmunidad celular como IL-2, IL-12 e INF- $\gamma$ y de factores anti-angiogénicos como angiostatina y endostatina. La disminución en la actividad de dichas células asesinas puede favorecer la progresión tumoral. $(21,22$, 23, 24) Macrófagos, monocitos, células mesoteliales peritoneales, fibroblastos y leucocitos son todos ellos capaces de sintetizar proteína $\mathrm{C}$ reactiva (PCR) y citoquinas pro inflamatorias como interleukina-1 (IL-1), interleukina-6 (IL-6) y factor de necrosis tumoral alfa (TNF- $\alpha$ ). Dentro de todos estos factores liberados y fáciles de estudiar, de hecho el más usado en la evaluación de la respuesta inflamatoria en una variedad de estudios es la proteína $\mathrm{C}$ reactiva (PCR), el cual es el reactante de fase aguda más extensamente estudiado, sus niveles aumentan generalmente entre 4 y 12 horas después de la cirugía con un pico a las 24-72 horas, permaneciendo elevados durante aproximadamente 2 semanas, a nivel celular se manifiesta como un incremento cuantitativo en la cifra de leucocitos totales y PMN, junto a un descenso en el número de linfocitos $\mathrm{T}$ (se produce leucocitosis con neutrofilia y linfopenia). Cualitativamente supone una reducción en la interacción entre linfocitos y macrófagos y de la quimiotaxis de los neutrófilos unido a una reducción de la hipersensibilidad retardada. $(25,26,27)$

Así pues, los procesos inflamatorios de origen químico o traumático se acompañan de estrés oxidativo. Una respuesta excesiva o una respuesta en una zona no afectada (los llamados segundos insultos) puede ser dañina. De hecho, la respuesta inflamatoria exagerada juega un papel fundamental en el desarrollo del síndrome isquemiareperfusión, el dolor, la hipercoagulación o síndromes inflamatorios que cursan con lesión endotelial como el síndrome de respuesta inflamatoria sistémica y promueven el desarrollo de las micrometástasis tumorales, lo cual guarda relación con la antítesis de lo deseado tras una cirugía oncológica. (27)

Ahora bien, y logrando consensuar teorías, visto que los opioides inhiben tanto la inmunidad humoral como la celular en humanos e incrementan la angiogénesis en condiciones basales pueden influir en la morbilidad y mortalidad de los pacientes oncológicos. Igualmente, en modelos animales se ha demostrado que los opioides inhiben la inmunidad si se administran vía sistémica pero no cuando la absorción es intratecal. Así para la mayoría de autores, la anestesia epidural puede ser protectora y atenúa la respuesta endocrina y metabólica tras cirugía mayor. (27) 
En otro orden de ideas, se conoce que los anestésicos locales pueden tener efecto antitumoral, afectan directamente la función de los polimorfonucleares, macrófagos y monocitos. Reducen su capacidad para migrar al foco inflamatorio e inhiben su estimulación, lo que evita una respuesta inflamatoria excesiva e incontrolada sin disminuir la respuesta inmune defensiva del huésped, también reducen la respuesta inflamatoria por dos vías de actuación: bloqueando la transmisión neural en el lugar del daño tisular y por sus propiedades anti-inflamatorias sistémicas. Así la lidocaína inhibe in vitro la proliferación de células tumorales de osteosarcoma y cáncer de lengua. Ahora bien, el propofol es el único anestésico que no promueve la inmunosupresión perioperatoria. $(28,29,30)$

En consecuencia, se planteó la siguiente hipótesis:

“Si los valores de proteína c reactiva y el índice neutrófilo-linfocito son significativamente menores en el grupo experimental, ambos medidos en el postoperatorio, entonces la técnica anestésica empleada se asocia con mejor control de la respuesta inflamatoria e inmune respectivamente. "

\section{OBJETIVOS}

\section{GENERAL:}

Evaluar la respuesta inflamatoria e inmunológica en pacientes oncológicos bajo anestesia multimodal libre de opioides combinada con epidural vs anestesia general inhalatoria en el área de quirófano del Hospital Dr. Luis Razetti, en Barinas, en el período comprendido entre enero 2016 hasta octubre 2017.

\section{ESPECÍFICOS:}

1. Caracterizar los grupos control y experimental según el IMC, talla, peso, sexo, edad, ASA, valores de proteína c reactiva e índice neutrófilos-linfocitos en el preoperatorio.

2. Identificar los valores de proteína c reactiva e índice neutrófilo-linfocito en el postoperatorio para los grupos control y experimental respectivamente.

3. Determinar los valores puntos de corte óptimos para la proteína c reactiva e índice neutrófilos-linfocitos en la población de estudio respectivamente. 
4. Analizar la variación de los valores obtenidos de proteína c reactiva e índice neutrófilos-linfocitos entre el pre y postoperatorio de los grupos control y experimental respectivamente.

5. Estimar la relación asociativa y causal del tipo de anestesia empleada con la modulación de la respuesta inflamatoria e inmune.

6. Describir el comportamiento transoperatorio para cada grupo en cuanto a variables hemodinámicas (FC, PAM), eventos de hipertensión e hipotensión arterial, necesidad de rescate analgésico y dolor en el postoperatorio inmediato.

En cuanto a los antecedentes de campo revisados en trabajos previos, que de una manera u otra guardan relación con el presente estudio y forman parte del sustento teórico y comparativo se consideran los siguientes: Hans J. Nielsen (2000) publicó un estudio retrospectivo en la revista Annals of Surgical un trabajo donde evaluó los valores séricos preoperatorios de la PCR en 594 pacientes con cáncer colorectal como variable dependiente para el pronóstico de sobrevida al cáncer colorectal hasta los 6.8 años y recurrencia tumoral, dónde niveles elevados de PCR en el preoperatorio eran consistentes con estadios avanzados de Duque, y recurrencia tumoral y pobre sobrevida, con una significancia $\mathrm{p}<0.0001$. Este estudio tenía los mismos criterios de exclusión similares a los que tiene el estudio actual: no haber recibido esteroides, quimio, radio, infecciones, transfusiones al menos a dos semanas previas a la cirugía. No fueron evaluados los niveles postoperatorios de la PCR, y fueron evaluados los pacientes para determinar sobrevida y recurrencia cada tres meses hasta los 6.8 años. (31) Asi mismo, Aristomenis (2006) publicó en Anesthesiology el artículo Can anesthetic technique for primary breast cancer surgery affect recurrence or metastasis? En este estudio prospectivo se incluyeron 129 pacientes para mastectomía y vaciamiento ganglionar axilar, los cuales fueron divididos en dos grupos, anestesia regional por bloqueo paravertebral y anestesia general inhalatoria, arrojando los siguientes resultados: sobrevida libre de recurrencia tumoral y metástasis $94 \%$ y $82 \%$ a los 2 años, y $94 \%$ frente a $77 \%$ a los 2 años y medio respectivamente con una $\mathrm{P}=0.012$. Este estudio sugiere que la anestesia regional promueve menor tasa de recurrencia tumoral y sobrevida al cáncer. (32)

Por su parte, Nora María (2011) publica en la revista de Anales de Cirugía Oncológica el trabajo titulado Intraoperative Epidural Analgesia Prevents the Early Proinflammatory Response to Surgical Trauma, con el cual demostró la atenuación de la respuesta pro inflamatoria y de la inmunosupresión post operatoria en pacientes con 
cáncer de colon, con el uso de analgesia epidural intraoperatoria frente al grupo que solo recibió anestesia general endovenosa. (33) Otro estudio, cuya autora Patricia Duque. Madrid (2012), en su tesis para optar al grado de Doctora titulada: Impacto de la técnica quirúrgica y anestésica sobre la respuesta inflamatoria y angiogénica en cirugía de tumor colorrectal, tenía como uno de sus objetivos específicos el estudiar la influencia de la anestesia epidural sobre la respuesta inflamatoria y angiogénica en cirugía abierta colorrectal. Usó mediciones séricas de PCR, IL-6 y otras interleuquinas, llegando a los siguientes resultados y conclusiones, la citoquina liberada por excelencia es la IL-6 y se obtuvieron niveles más bajos en los pacientes que recibieron analgesia epidural intraoperatoria, los niveles de la PCR se relacionaban con la magnitud del trauma quirúrgico, y llega a la conclusión que los anestésicos locales reducen la respuesta inflamatoria por dos vías de actuación: bloqueando la transmisión neural en el lugar del daño tisular y por sus propiedades antiinflamatorias sistémicas. Hace hincapié en los efectos no analgésicos de la analgesia epidural, los cuales van desde permitir una mecánica ventilatoria eficaz en el postoperatorio gracias al control del dolor, a nivel gastrointestinal, la analgesia epidural provoca una disminución de más del $35 \%$ en la resistencia de la arteria mesentérica superior dando lugar a vasodilatación regional sin que exista una redistribución del flujo sistémico ya que no se produce ningún cambio en la fracción de volumen sistólico que se deriva hacia el intestino, con disminución de las tasas de daño por reperfusión tisular y endotoxemias asociadas. (34) De la misma manera y en revisiones más actuales, precisamente en nuestro país la Dra. Morón Chacín, L (2016) en su tesis para optar al título de especialista en anestesiología, de la UCV, titulado Respuesta hemodinámica, leucocitaria y marcadores sistémicos de estrés en la anestesia total intravenosa manual versus anestesia general inhalatoria; un estudio longitudinal y prospectivo realizado en el Hospital Militar Dr. Carlos Arvelo de Caracas. El diseño contó con dos grupos, el primero que recibió anestesia total endovenosa con propofol y fentanil, y el segundo que recibió anestesia general inhalatoria. Como marcadores sistémicos de estrés tomaron los valores de glicemia sérica y cortisol sérico. Concluyendo que la anestesia total intravenosa bloquea efectivamente la respuesta hemodinámica, leucocitaria y los marcadores sistémicos de estrés generados por el trauma quirúrgico. En dicho estudio no se usa los valores de PCR como marcador de la respuesta inflamatoria, y solo se usa el conteo global de leucocitos como marcador de respuesta inmune, y no el índice de Zahorec (INL) preferido para este análisis, considerando la analogía con nuestro estudio por el empleo del propofol y no uso de agentes anestésicos volátiles, a diferencia 
de su estudio, nuestro grupo experimental evita el uso de opioides por las razones ya conocidas.

En cuanto a nuevas bases teóricas tenemos que Zahorec R. destaca la utilidad del índice de neutrófilos/linfocitos (INL) como parámetro fácil de obtener y que evalúa la intensidad del estrés y de la respuesta inflamatoria sistémica repercutiendo sobre la modulación del sistema inmune, una respuesta caracterizada por fiebre, leucocitosis, incremento en los niveles de proteínas de fase aguda tales como la proteína $\mathrm{C}$ reactiva (PCR), fibrinógeno, etc. El INL guarda una relación significativa y directamente proporcional con los valores de PCR, dado que la neutrofilia y la linfopenia asociada como respuesta al estrés están dadas por altas concentraciones de catecolaminas, cortisol, PCR. La linfopenia es causa de depresión del sistema inmune y mayormente de la inactividad y supresión de los linfocitos T CD4, o comúnmente conocidos como natural killer. Visto de esta manera, la evaluación de los valores de PCR e INL para correlacionarlos con la respuesta inflamatoria e inmune respectivamente en el postoperatorio, son medidas factibles, de bajo costo y recomendados por la literatura científica actual. Tenemos por ejemplo las recomendaciones del Dr. José Álvarez Vega, en su trabajo publicado en el 2014, en la Revista Mexicana de Anestesiología, titulado: ¿Cómo evaluar la respuesta anti-inflamatoria postoperatoria? En el cual recomienda el uso del índice de Zahorec (INL) y los valores de la PCR como indicadores de la respuesta inmune e inflamatoria respectivamente en los pacientes con cáncer.

Se considera los efectos de los anestésicos que se emplean en el estudio y de la analgesia peridural intra y postoperatoria sobre las respuestas del organismo ante la agresión quirúrgica. Tenemos que el propofol disminuye los valores de TGF-beta, miR21, efecto antiinflamatorio por diversos mecanismos, los no farmacológicos se deben al mantenimiento del flujo sanguíneo hepático y esto logra mantener un balance entre las citosinas pro y las anti-inflamatorias, aumentando la producción de IL-10, IL-1 y reduciendo los niveles de los radicales libres, otros efectos probados del propofol son la inactivación de las metaloproteasas implicadas en la diseminación tumoral. $(16,17,18)$ Por su parte el midazolam disminuye los valores de IL-8 con efecto pro-inflamatorio. (19) Y los anestésicos locales tales como la lidocaína y la bupivacaína inhibe el crecimiento, invasión y migración de células cancerígenas. Induce apoptosis en células cancerígenas, inhibe el receptor NMDA, inhibe r-Glicina, y sensibiliza a las células cancerígenas al efecto del cisplatino y otras drogas antineoplásicas. 
Además de tener efecto analgésico, antihiperalgésico y efecto protector sobre el sistema inmune ya que preserva el ratio Interferón Gamma/IL-4. (20, 21, 22) Con respecto a la ketamina se tiene información controversial, por un lado autores consideran el efecto anti-inflamatorio, evita la respuesta exagerada y se evidencia con disminución de marcadores inflamatorios (IL-6), además que a dosis sub anestésicas tiene efectos beneficiosos sobre la respuesta inmune durante y después de la cirugía $(23,24,25)$ y por otro lado un estudio en el 2003, publicado por Melamed R, en la revista Anestesia y Analgesia, realizado en ratas, a las cuales se les inyectó células cancerígenas de mamas, se determinó que la ketamina producía supresión de la actividad de las natural killer, y promovía la aparición de metástasis. (26). El uso de la Clonidina con efecto analgésico, no se ha visto relacionado con la promoción del crecimiento tumoral como si ha sido documentado para la dexmedetomidina en el cáncer de mama. (27) Y finalmente, la administración de sulfato de magnesio, provee efectos antinociceptivos, analgésicos, neuro y cardioprotectores además de tener efecto antitumoral, por el bloqueo de los canales de NMDA y los canales de calcio induciendo apoptosis tumoral. (28)

\section{MATERIAL Y MÉTODOS}

Por medio del paradigma positivista con el método cuantitativo se realizó una investigación de campo con nivel de profundidad explicativo y correlacional, del tipo ensayo clínico: grupo control y grupo experimental. Ensayo clínico abierto, y se aplicó el diseño Cuasi-experimental Pre-test y Pos-test en dos grupos no equivalentes, prospectivo y longitudinal, donde se evaluó la efectividad de una técnica anestésica multimodal endovenosa libre de opioides combinada con analgesia peridural descrita y propia del autor en comparación con la anestesia general inhalatoria con sevorane en cuanto a modulación de la respuesta inflamatoria e inmune, según valores plasmáticos de proteína $\mathrm{C}$ reactiva e índice neutrófilos/linfocitos respectivamente; siendo estas las principales variables dependientes del estudio. Dicho ensayo clínico se realizó en el Hospital Dr. Luis Razetti de Barinas en el período comprendido enero 2016 - octubre 2017. Previa aprobación por el Comité de Ética del Hospital, se incluyeron en el estudio un total de 44 pacientes, previa valoración preanestésica (Anexo-1) y consentimiento informado (Anexo-2); se asignaron de forma muestral intencional los pacientes que cumplieron con los criterios de inclusión a dos grupos: grupo control (los que necesitaron cirugías que incluyeron dermatomas superiores a T6), también denominado grupo A, o grupo AGI (por la técnica anestésica recibida, anestesia general inhalatoria); y grupo experimental 
(los que necesitaron cirugías que incluyeron dermatomas por debajo de T6), también denominado por el autor como grupo B, o grupo AMELO (por la técnica anestésica recibida, anestesia multimodal endovenosa libre de opioides).

La recolección de la información fue por la técnica de observación, hecha por el mismo autor del estudio y la variable independiente del estudio fue el tipo de técnica anestésica empleada, siendo esta la que expresa la relación causal que produce el resultado o efecto observado. Las variables dependientes: frecuencia cardíaca expresada en latidos por minuto, tensión arterial media expresada en $\mathrm{mm} \mathrm{Hg}$, necesidad de rescate analgésico intra-operatorio variable categórica dicotómica expresada en si o no, dolor post operatorio expresada en números según la escala de evaluación visual del dolor (EVA), niveles plasmáticos de proteína $\mathrm{C}$ reactiva expresado en $\mathrm{mg} / \mathrm{L}$ e índice neutrófilos/linfocitos pre y post operatorio a las 48 horas variable continua. Dentro de las variables intervinientes: sexo (Hombre o Mujer), edad (años, número entero), peso (Kg), talla (expresada en metros), IMC ( $\mathrm{Kg} / \mathrm{m} 2$ ), y clasificación ASA.

Población de estudio: representada por todos aquellos pacientes oncológicos que en algún momento han requerido intervención quirúrgica de electiva, atendidos en el Hospital Dr. Luis Razetti en Barinas, en el período comprendido de enero 2016 a octubre 2017.

Muestra Poblacional: pacientes oncológicos quirúrgicos, independiente del diagnóstico planteado, la muestra ha sido calculada sobre los datos obtenidos del Departamento de Estadísticas del Hospital Dr. Luis Razetti en Barinas, según fórmula de cálculo muestral para poblaciones finitas que introduce un error de estimación muestral de 0,09. El tamaño muestral estadísticamente significativo sería de 43 pacientes, por lo que se incluyeron 22 pacientes para cada grupo respectivamente, siendo en total 44 pacientes el tamaño de la muestra.

\section{Criterios de inclusión:}

- Pacientes oncológicos.

- Pacientes ASA II y III.

- Edad entre los 18 y 70 años.

- Consentimiento informado de aceptación.

\section{Criterios de exclusión:}

- Pacientes HIV positivos. 
- Hipertensos no controlados.

- Diabetes Mellitus.

- $\quad \mathrm{IMC}>=30$.

- Insuficiencia Renal Crónica.

- Pacientes que hayan recibido transfusiones de hemoderivados en los 15 días previos a la intervención, durante o después de ella en las 48 horas posteriores.

- Sintomáticos respiratorios en los 15 días previos a la cirugía.

- Pacientes que hayan recibido en los 30 días previos a la cirugía quimioterapia.

- Pacientes anémicos $\mathrm{Hb}<10 \mathrm{~g} / 1$.

Se empleó la observación directa, haciendo uso del Guión de Observación (Anexo3) contentivo de las variables a medir, el cual fue evaluado y aprobado, los datos de este instrumento se vaciaron en una hoja de recolección de datos. Se registraron los valores de la PCR y el valor del INL de 24 horas previas a la cirugía. El día de la intervención quirúrgica, con dos vías periféricas de calibre igual o mayor a $18 \mathrm{G}$, previo monitoreo básico con tensión arterial no invasiva, oximetría de pulso, capnografía, electrocardiografía de 3 derivaciones, frecuencia cardíaca, y temperatura axilar por monitor Ductus, se aplicaron las drogas pre-anestésicas y acto seguido la técnica anestésica propuesta según el grupo al que correspondía cada paciente.

\section{Técnica anestésica - anestesia general inhalatoria:}

Premedicación: Metoclopramida $10 \mathrm{mg}$ EV, Ranitidina $50 \mathrm{mg}$ EV, Ketoprofeno 100 mg EV, Antibiótico de elección.

Paciente en decúbito supino, preoxigenación durante 3 a 5 minutos con oxígeno al $100 \%$ por medio de máscara facial y válvula APL abierta, administración de las drogas de inducción: Midazolam 0.04mg/Kg EV, Lidocaína $1.5 \mathrm{mg} / \mathrm{Kg}$ EV, Fentanil 2 mcg/Kg $\mathrm{EV}$, Propofol $2 \mathrm{mg} / \mathrm{Kg} \mathrm{EV}$, Rocuronio $0.8 \mathrm{mg} / \mathrm{Kg}$ EV. Laringoscopia directa a los 3 minutos de administrar el relajante neuromuscular, se intuba al paciente con tubo endotraqueal, se verifica la correcta intubación, se fija el tubo y se conecta a ventilación mecánica según: volumen corriente $6-8 \mathrm{ml} / \mathrm{Kg}$, frecuencia respiratoria (FR) 12-14 respiraciones por minuto, PEEP 4-6 mm Hg, relación I:E 1:2, pausa inspiratoria 25\%, modo ventilatorio volumen control.

El mantenimiento de la anestesia se realizó con concentraciones variables de sevorane $2 \mathrm{Vol} \%$ de inicio, y según necesidad se administró dosis complementarias de 
fentanil de $0.5 \mathrm{mcg} / \mathrm{Kg} \mathrm{EV}$. Al finalizar la cirugía se realizó educción con reversión mediada del antagonismo de la neostigmina a dosis de $0.04 \mathrm{mg} / \mathrm{Kg}$ más atropina a dosis de $0.01 \mathrm{mg} / \mathrm{Kg} \mathrm{EV}$.

Técnica anestésica - anestesia multimodal endovenosa libre de opioides combinada con analgesia peridural:

Premedicación: Metoclopramida 10 mg EV, Ranitidina 50 mg EV, Ketoprofeno 100 mg EV, Antibiótico de elección.

Paciente sentado previa asepsia y antisepsia con yodo y alcohol, se identificó el espacio intervertebral correspondiente al dermatoma T6, infiltración de piel, tejido celular subcutáneo y planos profundos con lidocaína al 1\% $100 \mathrm{mg}$ volumen $10 \mathrm{cc}$, cantidad necesaria, luego se insertó unos $3 \mathrm{~cm}$ la aguja Tuohy \# 16G, y se localizó el espacio peridural con técnica pérdida de la resistencia con 5 cc de solución $0.9 \%$; al localizar el espacio peridural, se aspiró, comprobando la negatividad de líquido cefalorraquídeo y/o sangre y se realizó el test dose con $3 \mathrm{cc}$ de la mezcla para peridural ( Bupivacaína al $0.125 \%$ con 5 cc de Bupivacaína al $0.5 \%$ más 15 cc de Solución $0.9 \%$, volumen total 20 cc más adrenalina al 1: 200 000) se dejó catéter peridural 18G, se fijó, se acostó al paciente y se administró el restante volumen de la mezcla anterior.

Acto seguido se inició la infusión endovenosa de la mezcla denominada OFA (Anestesia Libre de Opioides) la cual se preparó: para cada volumen total de $100 \mathrm{cc} / \mathrm{hora}$, agregar ketamina a $0.12 \mathrm{mg} / \mathrm{Kg} /$ hora, lidocaína $2 \mathrm{mg} / \mathrm{Kg} /$ hora, MgSO4 10mg/Kg/hora y Clonidina $0.1 \mathrm{mcg} / \mathrm{Kg} /$ hora. Preoxigenación de 3 a 5 minutos con máscara facial, con oxígeno al 100\% y válvula de APL abierta.

A continuación, se administró las drogas de inducción: Midazolam $0.04 \mathrm{mg} / \mathrm{Kg} \mathrm{EV}$ (Dosis Prueba Benzodiacepinas) y se esperó 5 minutos para evaluar respuesta. A los 5 minutos:

- Paciente despierto, se administró dosis inducción a $0.2 \mathrm{mg} / \mathrm{Kg} \mathrm{EV}$ de Midazolam.

- Paciente somnoliento, responde y obedece órdenes, apertura ocular espontánea y al llamado, se administró dosis de inducción a $0.15 \mathrm{mg} / \mathrm{Kg}$ EV de Midazolam.

- Paciente dormido, no obedece órdenes verbales, se administró dosis de inducción a $0.12 \mathrm{mg} / \mathrm{Kg}$ EV de Midazolam. 
Se continuó con la administración de las demás:

- Lidocaína EV $1.5 \mathrm{mg} / \mathrm{Kg}$.

- Clonidina EV $0.5 \mathrm{mcg} / \mathrm{Kg}$.

- Ketamina EV $0.5 \mathrm{mg} / \mathrm{Kg}$.

- $\mathrm{MgSO} 42 \mathrm{~g} \mathrm{EV}$.

- Propofol $0.5 \mathrm{mg} / \mathrm{Kg} \mathrm{EV}$.

- Rocuronio $0.08 \mathrm{mg} / \mathrm{Kg} \mathrm{EV}$.

Se procedió a realizar la laringoscopia directa a los 3 minutos de administrar el relajante neuromuscular, se intubó al paciente con tubo endo-traqueal, se verificó la correcta intubación, se fijó el tubo y se pasó a ventilación mecánica según: volumen corriente 6-8 ml/Kg, FR 12-14 rpm, PEEP 4-6 mm Hg, relación I:E1:2, pausa inspiratoria $25 \%$, modo ventilatorio volumen control.

Después de la intubación endotraqueal se comenzó infusión de propofol a 0.5 $\mathrm{mg} / \mathrm{Kg}$ /hora pudiendo incrementarse o variar de acuerdo a los cambios hemodinámicos observados, de detectarse cifras elevadas de tensión arterial media superiores al $20 \%$ de la tensión arterial media basal se administró dosis de rescate analgésica con fentanil a $0.5 \mathrm{mcg} / \mathrm{kg} \mathrm{EV}$, la infusión de propofol se detuvo cuando se comenzó cierre de aponeurosis. Se repite la dosis de prueba de midazolam cada media hora hasta 30 minutos antes de la posible culminación de la cirugía. El rocuronio se repitió cada 30 minutos con solo una masa de la droga usada en la inducción del 10\%. La evaluación del dolor se realizó según la escala visual EVA en el postoperatorio hora 0 , y horas 8, 16 y 24 .

A las 48 horas de la cirugía se registraron los valores de PCR e INL respectivamente para cada miembro de los grupos estudiados.

Para el análisis estadístico se utilizó el programa SPSS para Windows versión 24.0. Se aplicaron medidas de tendencia central: media, desviación estándar (DE), rangos, intervalos de confianza del 95\% para las variables demográficas (edad, peso, talla, IMC, PCR pre operatoria e INL pre operatoria). Y para las variables categóricas ASA y Sexo se empleó el porcentaje. Para los análisis posteriores se emplearon las pruebas paramétricas T de Student pareadas, y T de Student para muestras independientes según correspondía; cumpliéndose los supuestos de normalidad (Shapiro Well) y homocedasticidad. Y se aplicaron pruebas no paramétricas: ANOVA de medidas repetidas, y Chi Cuadrado de Pearson a las variables continuas FC, PAM y Dolor 
respectivamente. Siempre usando un nivel estadísticamente significativo una $p<0.001$. En la confección de los gráficos se usó el programa Minitab ${ }^{\circledR}$ 17.1.0 y para el cálculo de los odds ratio se empleó la calculadora online de MedCalc Software bvba.

\section{RESULTADOS}

Se estudiaron 44 pacientes de ambos sexos, con clasificación ASA 2 y 3 de la Sociedad Americana de Anestesiología,

con edades comprendidas entre 29 y 70 años e IMC entre 20.2 y 29 , divididos en dos grupos de estudio con 22 pacientes en cada grupo: un grupo control o grupo A el cual recibió anestesia general inhalatoria (AGI) y un grupo experimental o grupo B el cual recibió anestesia multimodal endovenosa libre de opioides combinada con analgesia peridural (AMELO). Fueron excluidos 3 pacientes que no cumplieron con los criterios de inclusión. La metodología se describe en el flujograma Consort procedimental para ensayo clínico como vemos en la Figura 1. (Ver en Anexos)

Se tuvo un total de 38 pacientes ASA 2 que reportó un $86.4 \%$ y 6 pacientes ASA 3 para un $13.6 \%$. Mayor relación de hombres con respecto a las mujeres, un total de 28 para un $63.6 \%$ vs 16 mujeres con un $16.4 \%$ (ver Tabla 1 )

Tabla 1. Distribución demográfica

\begin{tabular}{lccc}
\hline \hline \multicolumn{1}{c}{ Variables } & $\begin{array}{c}\text { Grupo A (n=22) } \\
\text { media } \pm \text { DE(rango)* }\end{array}$ & $\begin{array}{c}\text { Grupo B (n=22) } \\
\text { media } \pm \text { DE(rango)* }\end{array}$ & $\mathrm{p} \S$ \\
\hline \hline Edad (años) & $50,3 \pm 12,5(29-70)$ & $50,2 \pm 9,5(33-65)$ & $\mathrm{p}=0,98$ \\
Peso (kg) & $75,7 \pm 9,9(60-95)$ & $72,7 \pm 13,2(50-93)$ & $\mathrm{p}=0,40$ \\
Talla (m) & $1,74 \pm 0,04(1,66-1,84)$ & $1,73 \pm 0,07(1,62-1,90)$ & $\mathrm{p}=0,46$ \\
IMC (kg/m²) & $24,8 \pm 2,59(20,2-29)$ & $24,1 \pm 3,18(19,0-28,7)$ & $\mathrm{p}=0,43$ \\
PCR $\dagger$ & $0,79 \pm 0,49(0,57-1,01)$ & $0,75 \pm 0,46(0,54-0,95)$ & $\mathrm{p}=0,77$ \\
INL $\dagger$ & $2,86 \pm 0,84(2,48-3,23)$ & $2,86 \pm 0,69(2,55-3,17)$ & $\mathrm{p}=0,98$ \\
\hline ASA + II / III & $20(90,9 \%) / 2(9,1 \%)$ & $18(81,8 \%) / 4(18,2 \%)$ & $38(86,4 \%) / 6(13,6 \%)$ \\
Sexo $\mathrm{H} / \mathrm{M}$ & $13(59,1 \%) / 9(40,9 \%)$ & $15(68,2 \%) / 7(31,8 \%)$ & $28(63,6 \%) / 16(36,4 \%)$ \\
\hline Fut Hoj
\end{tabular}

Fuente: Hoja de recolección de datos.

Notas: * media \pm desviación estándar (rango entre valor mínimo y valor máximo), $\uparrow$ valor corresponde al preoperatorio, y el rango corresponde a valores del IC 95\%, $\ddagger$ porcentaje correspondiente según grupo de estudio y total al final de la fila, $\S$ significación estadística igual a 0.01 para $\mathrm{T}$ de Student en muestras independientes, asumida la igualdad de varianzas, significación bilateral, con IC 98\%.

Como vemos en la Tabla 1 no hay diferencia estadísticamente significativa entre ambos grupos de estudio para las variables edad, peso, talla, IMC, y tampoco la hay para los valores de PCR e INL tomados en el preoperatorio, por lo que el sesgo tras la 
intervención queda reducido significativamente. Entonces tenemos que ambos grupos son homogéneos al comienzo del ensayo clínico para las variables PCR e INL las que son las variables dependientes del estudio más importantes con evaluación pre y post test.

Tabla 2. Valores de PCR e INL a las 48 horas.

\begin{tabular}{lllll}
\hline \hline & $\begin{array}{l}\text { Grupo A }(\mathrm{n}=22) \\
\text { media } \pm \text { DE }(\mathrm{IC9} \%)^{*}\end{array}$ & $\begin{array}{l}\text { Grupo B }(\mathrm{n}=22) \\
\text { media } \pm \mathrm{DE}(\mathrm{IC} 98 \%)^{*}\end{array}$ & $\mathrm{p} \S$ & $\begin{array}{l}(\mathrm{A}-\mathrm{B}) \\
(\mathrm{IC} 98 \%)^{* *}\end{array}$ \\
\hline \hline PCR 48h & $7,17 \pm 2,52(6,05-8,29)$ & $1,40 \pm 0,83(1,03-1,77)$ & $\mathrm{p}<0,001$ & $\begin{array}{l}5,76 \\
(4,35-7,17) \dagger\end{array}$ \\
INL 48h & $4,08 \pm 0,63(3,74-4,42)$ & $3,40 \pm 029(3,24-3,56)$ & $\mathrm{p}<0,001$ & $\begin{array}{l}0,68 \\
(0,31-1,04) \dagger\end{array}$ \\
\hline
\end{tabular}

Fuente: Hoja de recolección de datos.

Notas: * media \pm desviación estándar(IC98\%), ** diferencia entre la media Grupo A y Grupo B (IC98\%) y seguridad del 98\% que la diferencia es mayor a su límite inferior, $\S$ valor de p para un nivel de significancia de 0,01 para $\mathrm{T}$ de Student muestras independientes, $\uparrow$ para $(n=22)$ la prueba tiene una potencia cercana a $100 \%$ en la capacidad de detectar una diferencia de $5,76, \$$ para $(n=22)$ la prueba tiene una potencia cercana a $100 \%$ en la capacidad de detectar una diferencia de 0,68

Para ambas mediciones de los valores de PCR e INL en el postoperatorio a las 48 horas tras la intervención quirúrgica se reportó una diferencia positiva estadísticamente significativa para un nivel de significancia de 0.01 entre el grupo A y el grupo B, que plantea un incremento significativo y mayor en los valores de PCR e INL del grupo A en comparación con los valores del grupo B. Para la PCR el grupo control, el cual recibió anestesia general inhalatoria, tuvo una media de $7.17 \mathrm{y}$ el grupo experimental solamente ascendió a el valor promedio de 1.4, siendo la diferencia positiva para un valor de 5.76, con un p valor menor a 0.001 , siendo el tamaño de la muestra en cada grupo de 22 se estima una potencia de la prueba cercana al $100 \%$ en la capacidad de detectar una diferencia de 5.76 y una seguridad del $98 \%$ de que la diferencia es mayor a 4.35. Estos resultados pueden apreciarse mejor de forma gráfica en el Gráfico 1, ubicado en los anexos del presente trabajo.

Ahora bien, partiendo de los valores basales o preoperatorios de ambas variables dependientes (PCR e INL) se estimaron valores de punto de corte óptimos (PCO) según la fórmula: $\mathrm{PCO}=$ media $\pm 3 \mathrm{DE}$. Estos valores son de referencia para dicotomizar las variables continuas, y permiten establecer asociaciones de dependencia entre sus desviaciones de la normalidad y la variable independiente que es el tipo de técnica anestésica empleada (Tabla 3). 


\begin{tabular}{ccc} 
Variables & $\begin{array}{c}\text { Población }(\mathrm{n}=44) \\
\mathrm{x}^{-}+3 \mathrm{DS} \dagger\end{array}$ & $\mathrm{p} \dagger$ \\
\hline \hline PCR $^{*}$ & 2,2 & $<0.01$ \\
INL* $^{*}$ & 5 & $<0.01$ \\
\hline
\end{tabular}

Fuente: Hoja de datos.

Nota: $†$ (valor obtenido de la media +3 desviaciones estándar), * valores preoperatorios de la población en estudio, valor estimado es el Punto de Corte Óptimo, permite dicotomizar la variable y establecer valor de comparación entre las medias, estadísticamente significativa. $\$ \mathrm{p}$ valor para un nivel de significación de 0.01 .

En relación a la variación de los valores de PCR e INL a las 48 horas con relación a los basales del preoperatorio se puede observar lo siguiente en la Tabla 4, el aumento de los valores con respecto a los basales fue estadísticamente significativo para las dos variables (PCR e INL) con una $\mathrm{p}<0.01$ en ambos grupos, tanto para los que son del grupo A que recibieron anestesia general inhalatoria como para los que recibieron anestesia multimodal endovenosa libre de opioides combinada con analgesia peridural del grupo B. Observándose un aumento más marcado en los valores de PCR para el grupo A en comparación con el grupo B, donde el aumento fue de 6.38, estimado por una prueba $\mathrm{T}$ de Student para muestras pareadas con un nivel de significancia de $0.01 \mathrm{y}$ una $\mathrm{p}$ valor $<0.01$, y con un intervalo de confianza del $98 \%$ para la diferencia entre 5.06 y 7.68, con una potencia de la prueba de estimar una diferencia de 5.06 cercana al $100 \%$. No sucedió así con la diferencia registrada en el grupo B, que fue de 0.65 con un intervalo de confianza del $98 \%$ entre 0.24 y 1.07 .

Tabla 4. Variación de los valores de PCR e INL

\begin{tabular}{lllllc}
\hline \hline \multirow{2}{*}{ Variables } & Grupo & Pre-O* & Post-O** & Diferencia*** & p valor \\
& & & & & \\
\hline \hline PCR & Grupo A & 0,79 & 7,17 & $6,38 \dagger$ & $\mathrm{p}<0,01$ \\
& Grupo B & 0,75 & 1,4 & $0,65 \ddagger$ & $\mathrm{p}<0,01$ \\
INL & Grupo A & 2,86 & 4,08 & $1,24 ¥$ & $\mathrm{p}<0,01$ \\
& Grupo B & 2,86 & 3,4 & $0,54 £$ & $\mathrm{p}<0,01$ \\
\hline
\end{tabular}

Fuente: Hoja de recolección de datos.

Notas: * valores del pre-operatorio, $* *$ valores del post-operatorio, *** diferencia entre el valor del post-operatorio con el pre-operatorio, § p valor de la T de Student para muestras pareadas y nivel de significancia de 0,01 , $\uparrow$ la media de PCR48 es mayor que PCRPre en el nivel de significancia de 0,01 , puede estar $98 \%$ seguro de que 
la diferencia verdadera se encuentra entre 5,06 y 7,68, y la potencia de la prueba cercana al 100\%, ya que con una diferencia de 2,01 es igual al 90\%, $\ddagger$ la media de PCR48 es mayor que PCRPre en el nivel de significancia de 0,01 , puede estar $98 \%$ seguro de que la diferencia verdadera se encuentra entre 0,24 y 1,07, y la potencia de la prueba del $90 \%$, ya que con una diferencia de 0,64 es igual al $90 \% ¥$ la media de INL48 es mayor que INLPre en el nivel de significancia de 0,01, puede estar 98\% seguro de que la diferencia verdadera se encuentra entre 0,73 y 1,76 , y la potencia de la prueba cercana al 100\%, ya que con una diferencia de 0.79 es igual al $90 \%$, £ la media de INL48 es mayor que INLPre en el nivel de significancia de 0,01 , puede estar $98 \%$ seguro de que la diferencia verdadera se encuentra entre 0,23 y 0,85 , y la potencia de la prueba cercana al $100 \%$, ya que con una diferencia de 0.45 es igual al $90 \%$

Además, como se puede observar la media de la PCR en el postoperatorio del grupo A es superior al punto de corte óptimo estimado ( $\mathrm{PCO}$ para $\mathrm{PCR}=2.2)$ para esta variable, por lo que su aumento es superior a la media de su valor basal preoperatorio más 3 desviaciones estándar por encima, se entiende por lo tanto que los valores de PCR tras haber recibido anestesia general inhalatoria aumentarán muy significativamente por encima de lo normal esperado, y esto refleja el efecto que tiene la técnica anestésica empleada. No sucede así con los valores del INL que a pesar de que aumentaron significativamente en el postoperatorio con respecto a sus valores basales en ambos grupos de estudio, ningún grupo tuvo una media superior a su punto de corte óptimo (PCO para $\mathrm{INL}=5)$.

Tabla 5. Asociación tipo de técnica anestésica empleada y resultados de PCR e INL a las 48 horas según puntos de corte

\begin{tabular}{|c|c|c|c|c|}
\hline Efecto & \multicolumn{2}{|c|}{ PCR* } & \multicolumn{2}{|c|}{$\mathrm{INL} * *$} \\
\hline Grupo & $>2,2$ & $<2,2$ & $>5$ & $<5$ \\
\hline AGI (A) & $21-95,5 \%$ & $1-4,5 \%$ & $4-18,2 \%$ & $18-81,8 \%$ \\
\hline (FE) & 12 & 10 & 2 & 20 \\
\hline AMELO (B) & $3-13,6 \%$ & $19-86,4 \%$ & $21-95,5 \%$ & $1-4,5 \%$ \\
\hline (FE) & 12 & 10 & 19,5 & 2,5 \\
\hline
\end{tabular}

Fuente: Hoja de recolección de datos.

Notas: * Chi-cuadrado de Pearson 29,7 ( $\mathrm{gl}=1), \mathrm{p}<0,001$ con nivel de significancia de $0,01,0$ casillas $(0,0 \%)$ han esperado un recuento menor que $5, \mathrm{~V}$ de Cramer de 0,82 (asociación muy fuerte y directamente proporcional). $\quad * *$ Chi-cuadrado de Pearson 
$2,03(\mathrm{gl}=1), \mathrm{p}=0,15$ con nivel de significancia de $0,01,2$ casillas $(50 \%)$ han esperado un recuento menor que 5 y se estima la prueba exacta de Fisher $\mathrm{p}=0,35, \mathrm{~V}$ de Cramer de 0,21 (asociación muy baja).

En relación al tipo de técnica anestésica empleada con los resultados de PCR e INL a las 48 horas, estableciendo estas variables como categóricas dicotómicas se observa en la Tabla 5 que para ambos grupos de estudio se realizó una distribución de frecuencias tipo tabla de contingencias $2 \times 2$ para cada variable en particular y se realizaron las pruebas estadísticas de Chi cuadrado de Pearson para determinar el grado de asociación y dirección del tipo de técnica anestésica empleada con el aumento sobre los valores de puntos de corte óptimos estimados, para la PCR un valor de corte de 2.2 y para el INL un valor de 5. En el caso de la PCR la técnica anestésica general inhalatoria está estadísticamente significativa asociada al aumento de sus valores por encima de 2.2 con un nivel de significancia de 0.01 , una $\mathrm{p}<0.001$, un valor de Chi cuadrado de Pearson de 29.7 (gl=1) y una $\mathrm{V}$ de Cramer de 0.82 que se interpreta como una asociación muy fuerte y directamente proporcional. En cambio, con respecto al INL no se encontró el mismo resultado, porque el Chi cuadrado de Pearson arrojado por el SPSS fue de 2.03 (gl=1) con un nivel de significancia de 0.01 y una $p=0.35$, como el valor de $p$ valor es mayor a el nivel de significancia no se rechaza la hipótesis nula estadística que dice que las variables no guardan relación de dependencia, y evidentemente se puede constatar con el valor de la V de Cramer de 0.21 que se interpreta como una asociación (de haberla) muy baja.

Como también vemos en el Gráfico 2, el cual refleja la Odds Ratio para la relación entre la técnica anestésica empleada con el aumento o disminución de los valores de PCR e INL a las 48 horas de postoperatorio tenemos que la razón entre ocurrencia de que aumente el valor de la PCR $>2.2$ vs que no aumente es 138 veces mayor en pacientes del grupo A que recibieron anestesia general inhalatoria en comparación con los del grupo B que recibieron AMELO, siendo esta asociación estadísticamente significativa para un nivel de significancia del 0.05 con un intervalo de confianza del 95\% que no incluye al 1 entre 12.7 y 1390. Se puede interpretar también de la siguiente forma, existe una probabilidad del 99\% que aumenten los valores de PCR por encima de 2.2 tras tener valores basales como se reflejan en la Tabla 1 si se recibe anestesia general inhalatoria (AGI) vs la probabilidad del $1 \%$ cuando se recibe anestesia multimodal endovenosa libre de opioides (AMELO). 
No ocurre lo mismo con el INL, para el cual se obtuvo un OR de 0.01 con un IC $95 \%$ entre 0.00 y 0.10 , que no incluye el 1 pero siendo valores x debajo de la unidad, no existe una asociación estadística significativa, se interpreta como la razón entre ocurrencia de que aumente el valor del INL por encima de 5 vs que no aumente es de 0.01 veces mayor en pacientes que recibieron AGI en comparación de aquellos que recibieron AMELO y también se entiende que la probabilidad de obtener valores por encima de 5 en el INL tras recibir una AGI es del $0.9 \%$ vs una probabilidad de obtener valores por debajo de 5 de un $99.1 \%$ si se recibe AMELO, aquí destaca el papel protector y modulador del sistema inmune de la técnica anestésica en el grupo experimental más que la inmunosupresión que pudiera causar la AGI.

En el análisis intraoperatorio de ambos grupos de estudio se evaluó el comportamiento de la presión arterial media y de la frecuencia cardíaca promedio en distintos tiempos, para lo cual se procesaron los datos con un ANOVA de dos factores con medidas repetidas en el factor tiempo y se resumieron en la Tabla 6; también consulte el Gráfico 3 y Gráfico 4 respectivamente para la mejor interpretación de los resultados.

Gráfico 2: Odds Ratio para relación entre técnicas anestésicas y aumento sobre valores de los puntos de corte para la PCR y el INL

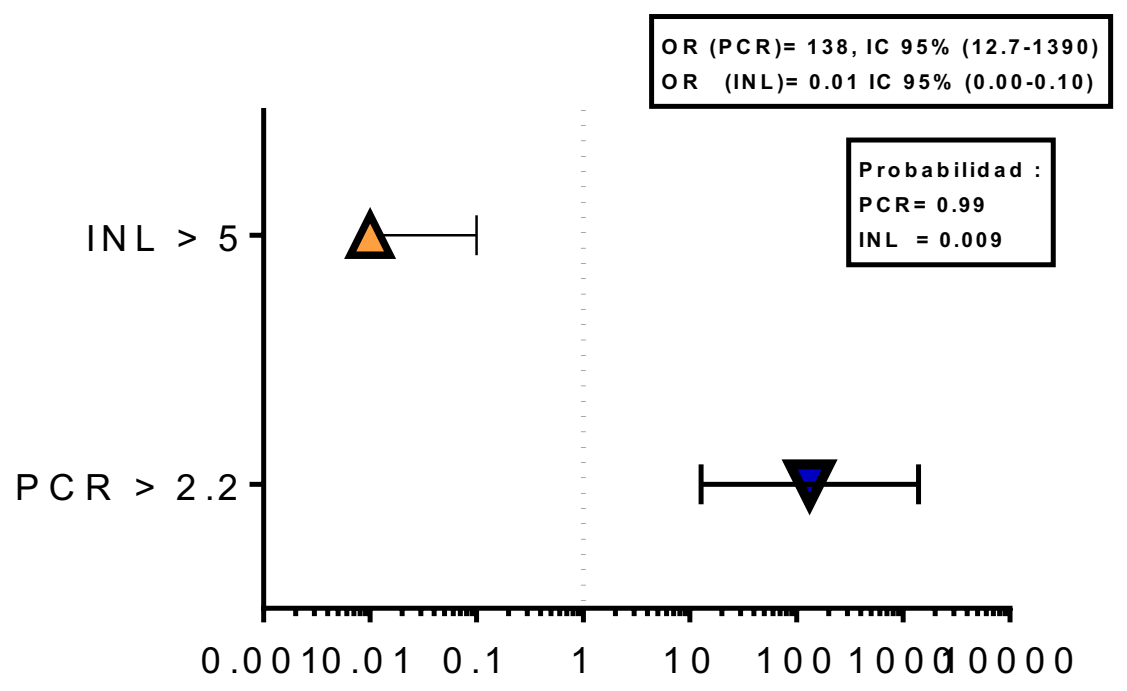

Odds ratio

Tabla 6: Comparación por grupos de estudio de las medias según tiempos intraoperatorios de la presión arterial media y la frecuencia cardiaca

\begin{tabular}{llllllll}
\hline \hline Parámetro & Grupo & T0 & T1 & T2 & T3 & T4 & T5 \\
\hline \hline \multirow{2}{*}{ PAM* } & Grupo A & $84,7 \pm 4,8$ & $90,9 \pm 5,5$ & $90,5 \pm 3,8$ & $90,5 \pm 2,6$ & $91,1 \pm 2,1$ & $89,9 \pm 3,2$ \\
& Grupo B & $86,3 \pm 3,7$ & $85,4 \pm 4,2$ & $86,5 \pm 3,6$ & $86,4 \pm 3,2$ & $85,7 \pm 2,7$ & $85,6 \pm 3,4$
\end{tabular}


$\mathrm{FC}^{* *}$

Grupo A $\quad 84,7 \pm 3,3 \quad 90,6 \pm 3,8 \quad 86,4 \pm 3,6 \quad 85,2 \pm 4,2 \quad 85,2 \pm 4,2 \quad 86,4 \pm 2,7$

Grupo B $\quad 84,9 \pm 3,1 \quad 73,3 \pm 2,3 \quad 72,4 \pm 2,0 \quad 71,3 \pm 2,9 \quad 71,3 \pm 2,9 \quad 77,5 \pm 3,8$

Fuente: Hoja de recolección de datos.

Notas: T0 Basal, T1 1 minuto tras la intubación orotraqueal, T2 1 minuto tras la incisión de piel, T3 a los 15 min tras última medición, T4 a los 15 minutos tras la última medición, T5 1 minuto tras cierre de piel. * Presión arterial media \pm desviación estándar con nivel de significancia al $0,01, * *$ frecuencia cardiaca \pm desviación estándar con nivel de significancia al 0,01. Análisis estadístico en SPSS con ANOVA de medidas repetidas para una significación de 0,01 .

El ANOVA medidas repetidas para los factores Grupo vs Tiempo, estimando para el factor tiempo las variaciones intragrupales de la presión arterial media (T0, T1, T2, T3, T4 y T5) cuyos tiempos de medición fueron expuestos con anterioridad a este análisis y para el factor grupo ( Grupo A y Grupo B) nos ofrece valores para un nivel de significación de 0.01 ; donde las covarianzas de la presión arterial media en sus diferentes tiempos de medición intraoperatorio son iguales entre los dos grupos estudiados con una F 1.08 y una significación mayor a 0.01 de 0.357 , por lo que se asume que no existe diferencia entre las varianzas por pares en cada tiempo de medición intraoperatorio. La diferencia de medias entre el grupo A y el grupo B es positiva y significativa con un valor de $3.6 \mathrm{~mm} \mathrm{Hg}$, un $\mathrm{p}<0.001$, ajustado con Bonferroni. Pero estimamos estas diferencias clínicamente no significativas porque no rebasan el $20 \%$ que se acepta de aumento o disminución de la presión arterial media. La prueba univariada, que prueba el efecto de Grupo, tiene una $\mathrm{F}$ de 39.47 , con una $\mathrm{p}<0.001$, y un eta cuadrado parcial de 0.485 que nos dice que la variación de la presión arterial media por efecto de grupo o de la técnica anestésica empleada tiene una potencia de efecto cercana al 50\%. La diferencia de medias en el tiempo T0 no es estadísticamente significativo, en el resto de los tiempos evaluados si lo es, pero con un IC 99\% para la diferencia entre los valores máximos encontrados de \pm 9.4 y \pm 9.4 . En el grupo A hubo diferencias estadísticamente significativas entre el T0 con el resto de los tiempos, pero ya el tiempo T1 se mantiene sin diferencias significativas con respecto al T2, T3, T4 y T5. Se evidencia por tanto un aumento de la presión arterial media basal pero no mayor al $20 \%$ y se mantiene estable sin variaciones durante todo el tiempo quirúrgico.

Mejor comportamiento de la PAM tuvo el grupo B porque no existió diferencias significativas intragrupales entre los tiempos evaluados. Pero de forma global el comportamiento intraoperatorio de la presión arterial media para ambos grupos fue 
estable dentro de los parámetros hemodinámicos aceptados con significación estadística de 0.01 y un $p$ valor $<0.001$.

En cuanto al comportamiento de la frecuencia cardiaca el grupo A experimentó un aumento significativo hacia el T1, pero dentro de rangos que no sobrepasaron el $20 \%$ estimado de variación hemodinámica aceptable, para luego disminuir cercano a valores basales en el resto del tiempo quirúrgico. Diferente a lo ocurrido en el grupo B que experimentó una disminución de la frecuencia cardiaca media hacia el tiempo T1 tampoco clínicamente significativa y se mantuvo en ese orden de frecuencias medias hasta que experimenta un aumento significativo en el T5, pero sin recuperar los valores basales. El ANOVA medidas repetidas arrojó valores para la prueba de efectos inter sujetos, una $\mathrm{F}$ de 340.26 con $\mathrm{p}<0.001$ y un eta cuadrado parcial de 0.89 para el efecto grupo. No hubo diferencias estadísticas significativas para las medias de FC entre los grupos en el T0, una $\mathrm{p}=0.82$, para el resto de los tiempos las diferencias de medias fueron significativas y todas fueron positivas cuando fueron estimadas entre el grupo A y el grupo B, con una diferencia mínima en T5 de 8.9 y una máxima en T2 de 17.3.

Ahora, en la Tabla 7 tenemos el análisis de la asociación que existe entre la técnica anestésica empleada y los eventos que se relacionan: hipotensión arterial, hipertensión arterial y necesidad de rescate analgésico con fentanil, todos ellos en el intraoperatorio.

Tabla 7. Asociación tipo de técnica anestésica empleada e incidencia de eventos de hipotensión, necesidad de rescate analgésico e hipertensión arterial respectivamente en el intraoperatorio

\begin{tabular}{lllllll}
\hline \hline Efecto & \multicolumn{2}{l}{ Hipotensión* } & \multicolumn{2}{l}{ Rescate** } & \multicolumn{2}{l}{ Hipertensión*** } \\
Técnica & si & no & si & no & si & no \\
\hline \hline AGI (A) & $2(9,1 \%)$ & $20(90,9 \%)$ & $12(54,5 \%)$ & $10(45,5 \%)$ & $10(45,5 \%)$ & $12(54,5 \%)$ \\
AMELO (B) & $4(18,2 \%)$ & $18(81,8 \%)$ & $1(4,5 \%)$ & $21(95,5 \%)$ & $1(4.5 \%)$ & $21(95,5 \%)$ \\
\hline
\end{tabular}

Fuente: Hoja de recolección de datos.

Notas: * Chi-cuadrado de Pearson $0,77(\mathrm{gl}=1), \mathrm{p}=0,38$ con nivel de significancia de $0,01,2$ casillas $(50 \%)$ con recuento esperado menor que 5, prueba exacta de Fisher $\mathrm{p}=0,66, \mathrm{~V}$ de Cramer de 0,13 y Phi de -0,13 (asociación muy débil e inversamente proporcional). ${ }^{* *}$ Chi-cuadrado de Pearson 13,2 ( $\left.\mathrm{gl}=1\right), \mathrm{p}<0,001$ con nivel de significancia de $0,01,0$ casillas $(0,0 \%)$ con recuento esperado menor que $5, \mathrm{~V}$ de Cramer de 0,55 y Phi de 0,548 (asociación moderadamente fuerte y directamente proporcional), *** Chi-cuadrado de Pearson 9,81 ( $\mathrm{gl}=1$ ), $\mathrm{p}=0,002$ con nivel de significancia de $0,01,0$ casillas $(0,0 \%)$ con recuento esperado menor que $5, \mathrm{~V}$ de Cramer de 0,47 y Phi de 0,478 (asociación moderadamente fuerte y directamente proporcional) 
En primer lugar, para determinar la relación de asociación entre la variable independiente técnica anestésica empleada y la variable dependiente hipotensión arterial durante el intraoperatorio (ambas variables categóricas), se realizó la presentación de los datos en tablas de contingencia $2 \times 2$ y se realizó el análisis estadístico de Chi cuadrado de Pearson para un nivel de significancia del 0.01 , obteniéndose un valor de Chi cuadrado de Pearson de $0.77(\mathrm{gl}=1)$ y una $\mathrm{p}$ valor de 0.38 ; como la $\mathrm{p}$ valor es mayor al nivel de significancia alfa de 0.01 se acepta la hipótesis nula de la prueba estadística que nos dice que entre las variables no hay asociación estadísticamente significativa, con la probabilidad de un erro tipo I de solo un 1\%. Y como se obtuvieron 2 casillas con recuento esperado menor a 5 se realizó la prueba exacta de Fisher que nos arrojó una p valor de 0.66, también se acepta por tanto la hipótesis nula estadística, asumiendo que el tipo de técnica anestésica empleada no está asociado con la presencia de eventos de hipotensión arterial en el intraoperatorio, por lo tanto el comportamiento en los dos grupos en este sentido es similar y no existen diferencias significativas para decir que una técnica nos induce más que la otra hipotensión arterial en el transoperatorio.

Ahora bien, en cuanto a la relación entre la técnica anestésica empleada con la necesidad de rescate analgésico en el intraoperatorio se realiza igualmente una prueba Chi Cuadrado de Pearson, cuyo valor del estadígrafo es de $13.2(\mathrm{gl}=1)$, y un valor de $\mathrm{p}<0,001$ para un nivel de significancia de 0,01 , se obtuvieron 0 casillas $(0,0 \%)$ con recuento esperado menor que 5; al ser el $\mathrm{p}$ valor menor al nivel de significancia alfa se rechaza la hipótesis estadística nula y se acepta la alternativa, para la cual si hay relación de asociación entre las variables y por lo tanto se estima el valor $\mathrm{V}$ de Cramer que fue de 0,55 y Phi de 0,548 esto se traduce que la asociación además de existir es moderadamente fuerte y directamente proporcional, que significa que la necesidad de rescate analgésico está asociada al empleo de la técnica anestesia general inhalatoria empleada en el grupo A.

De igual manera, se estimó la relación de asociación con la presencia de eventos de hipertensión arterial, el cual tuvo un valor de Chi Cuadrado de Pearson 9,81 ( $\mathrm{gl}=1)$, con una $p=0,002$ rechazándose la hipótesis nula en el nivel de significancia de $0,01,0$ casillas $(0,0 \%)$ con recuento esperado menor que $5, \mathrm{~V}$ de Cramer de 0,47 y Phi de 0,478 para lo cual la asociación es moderadamente fuerte y directamente proporcional al empleo de la técnica anestesia general inhalatoria. 
A estas relaciones de asociación entre las técnicas anestésicas empleadas con los eventos intraoperatorios evaluados también se le calculó su Odds Ratio (OR) individual con nivel de significancia del 0.05 para intervalos de confianza del 95\% de tal forma que la relación de asociación sea estadísticamente considerada una relación causal.

Ver Gráfico 5, en el cual vemos reflejado los valores de los OR: para la hipotensión arterial un OR de 0.45 con IC $95 \%$ de $0.07-2.76$, en vista que el intervalo incluye el 1 , se concluye que entre la variable independiente técnica de anestesia empleada y la hipotensión arterial no hay relación de asociación ni causal, con una probabilidad de cometer un error tipo I de un 5\%. Para la necesidad de rescate analgésico se tuvo el valor de OR de 25.2 con un IC 95\% de 2.86-221.7, y como no incluye al 1 en su intervalo de confianza es estadísticamente significativa la relación causa-efecto entre la técnica anestésica general inhalatoria con la necesidad de rescates analgésicos en el intraoperatorio y una probabilidad asociada al OR de 0.96, que se entiende como que es más probable en un $96 \%$ que se necesite de recate analgésico en el grupo A frente a que se necesite rescate analgésico en el grupo B en un 4\%. Y finalmente, para el análisis de la ocurrencia de eventos de hipertensión arterial se obtuvo un OR de 17.5 con IC 95\% de 1.99-153.97, y al no incluir tampoco al 1 en su intervalo de confianza la relación entre dar anestesia general inhalatoria y la ocurrencia de eventos de hipertensión arterial es significativa, entiéndase de la siguiente forma: la razón entre la ocurrencia de eventos de hipertensión arterial vs que no se den, es 17.5 veces mayor en pacientes del grupo A, o sea, en los que reciban anestesia general inhalatoria, en comparación con los del grupo B. Y la probabilidad asociada a su OR es de 0.94 , es 94\% más probable los eventos de hipertensión arterial en aquellos pacientes que reciban anestesia general inhalatoria frente al 6\% de probabilidad de desarrollar hipertensión arterial en los que reciban AMELO.

Tabla 8: Dolor según score EVA categorizado por grupos de estudio en las primeras 24 horas del post-operatorio

\begin{tabular}{llllll}
\hline \hline Tiempo & Grupo & $\begin{array}{l}\text { sin dolor } \\
0\end{array}$ & $\begin{array}{l}\text { leve } \\
(1 \mathrm{a} \mathrm{3})\end{array}$ & $\begin{array}{l}\text { moderado } \\
(4 \mathrm{a} 6)\end{array}$ & $\begin{array}{l}\text { severo } \\
\text { (7 a 10) }\end{array}$ \\
\hline \hline \multirow{2}{*}{$0 \mathrm{~h}$} & $\mathrm{~A}$ & $15(68 \%)$ & $2(9 \%)$ & $4(18 \%)$ & $1(5 \%)$ \\
& $\mathrm{B}$ & $22(100 \%)$ & 0 & 0 & 0 \\
\hline \multirow{2}{*}{$8 \mathrm{~h}$} & $\mathrm{~A}$ & $2(9 \%)$ & $14(64 \%)$ & $5(22 \%)$ & $1(5 \%)$ \\
& $\mathrm{B}$ & $22(100 \%)$ & 0 & 0 & 0 \\
\hline \multirow{2}{*}{$16 \mathrm{~h}$} & $\mathrm{~A}$ & $2(9 \%)$ & $2(9 \%)$ & $16(73 \%)$ & $2(9 \%)$ \\
\cline { 4 - 7 } & $\mathrm{B}$ & $12(55 \%)$ & $7(32 \%)$ & $3(13 \%)$ & 0 \\
\hline $2 \mathrm{~h}$ & $\mathrm{~A}$ & $1(5 \%)$ & $5(22 \%)$ & $9(41 \%)$ & $7(32 \%)$ \\
\hline
\end{tabular}




\section{B $\quad 12(55 \%)$}

$10(45 \%)$

0

0

Fuente: Hoja de recolección de datos.

Nota: Análisis estadístico con SPSS en ANOVA de medidas repetidas con un nivel de significación de 0.01 .

En relación al dolor evaluado (ver Tabla 8)(Gráfico 6, en anexos) según el score EVA en los tiempos $0,8,16, \mathrm{y} 24$ horas en el postoperatorio para cada grupo en estudio se tienen los siguientes resultados, el grupo B durante las primeras 8 horas no experimentó dolor, el $100 \%$ de los pacientes referían un EVA de 0 puntos, y el dolor experimentado a las 16 y 24 horas fue categoría leve, con medias de 1.23 y 0.82 respectivamente, en ningún momento de las 24 horas los pacientes necesitaron rescate analgésico con opioides, solo recibieron dosis suplementarias de Bupivacaína al $0.0625 \%$ en bolos cada 2 horas volumen $12 \mathrm{cc}$ si manifestaban la necesidad de analgesia. No sucedió lo mismo en el grupo A, teniendo un $68 \%$ a las 0 horas, en sala de recuperación post anestésica dolor leve, promedio 1.32 que requirieron rescate con ketoprofeno $100 \mathrm{mg}$ EV más dipirona $1 \mathrm{~g} \mathrm{IM}$, con alivio del dolor satisfactorio. Pero se registró desde la hora 0 que ya este grupo tenía un paciente para un 5\% que experimentó dolor severo, y a las 8 horas igual 5\%, a las 16 horas se incrementó a un 9\% y finalmente a las 24 horas un 32\%. Para el análisis estadístico se usó el SPSS una corrida de ANOVA con medidas repetidas para un nivel de significación de 0.01. Según las pruebas univariadas tuvo una $\mathrm{F}$ de $57.9(\mathrm{gl}=1)$, prueba el efecto del grupo a que pertenece cada paciente sobre su EVA, con un eta parcial al cuadrado de 0.58 que refiere que la potencia de la prueba es alta de un $58 \%$ en estimar las diferencias estadísticamente significativas entre las variaciones por tiempo de las medias marginales estimadas debido al efecto que tiene el grupo al que pertenecen, reportando un $\mathrm{p}$ valor menor a 0.0001 por lo que se rechaza la hipótesis estadística de nulidad y se acepta la alternativa, que refiere que existen diferencias significativas entre las medias en cada tiempo evaluado según grupos de estudio. Ahora bien, para las pruebas multivariantes donde cada F prueba el efecto multivariante del Tiempo, se basan en las comparaciones por parejas linealmente independientes entre las medias marginales estimadas, se tienen unas F iguales para Lambda de Wilks, Traza de Pillai, Traza de Hotelling y Raíz mayor de Roy de 57.97 (gl=3), con un eta cuadrado parcial de 0.83 que refiere una potencia de $83 \%$ atribuible al efecto tiempo en las variaciones del EVA. En resumen, las diferencias del EVA evaluadas para cada grupo y en todos los tiempos son mayormente atribuibles al factor tiempo que al factor grupo. Para todas las comparaciones por parejas entre el grupo control y el experimental las diferencias fueron significativas, $y$ en las variaciones del EVA dentro del grupo control hubo diferencias significativas 
entre la hora 0 y la hora 8 , pero no hubo diferencias significativas entre las 16 y 24 horas, asumiendo entonces que el grupo que recibió anestesia general inhalatoria tuvo dolor leve hasta las primeras 8 horas con un IC 98\% de 1.9-3.8. Y para el grupo experimental, todas las comparaciones de las medias del EVA en todos sus tiempos no tuvieron diferencias estadísticamente significativas, y fue solo en dos evaluaciones que tuvieron dolor leve, a las 16 y 24 horas para un IC 98\% de 0.7-2.5.

\section{DISCUSIÓN}

A partir de los hallazgos encontrados, se aceptó la hipótesis de que la técnica anestésica AMELO empleada se asocia con mejor control de la respuesta inflamatoria e inmune respectivamente en las cirugías oncológicas. Y por lo tanto la futura aplicación de esta técnica anestésica podría tener implicaciones prácticas en los outcomes de las cirugías oncológicas practicadas, con tasas inferiores de morbi-mortalidad, para lo cual futuros estudios son necesarios para comprobar la existencia de resultados similares en diseños ortogonales.

Limitaciones del estudio estuvieron en las variaciones intrasujetos con relación a sus necesidades analgésicas, y el no haber contado con un diseño ortogonal en cuanto a los diagnósticos pre operatorios y técnicas quirúrgicas empleadas; entendido que el tamaño de la incisión quirúrgica, y la magnitud del daño tisular se relaciona con la respuesta inflamatoria de forma directa y proporcional. Dichas limitaciones fueron controladas dado los valores sin diferencias significativas en el pre operatorio de las variables independientes. Además, se cumplió con un proceso de muestreo con criterios de inclusión y exclusión, y pruebas estadísticas paramétricas potentes con nivel de significancia de 0.01 y con un tamaño muestral suficiente para no cometer un error beta de 5\% que es aquel error que se comete al aceptar la hipótesis nula cuando esta sea falsa, es decir, la probabilidad de falsos negativos.

No existen estudios previos en donde se haya evaluado la respuesta inflamatoria e inmune en pacientes oncológicos al recibir específicamente anestesia multimodal endovenosa sin opioides y combinada con analgesia peridural, con el uso de drogas específicas de este estudio; y por ello se revisó algunos estudios, donde se evaluó los valores de PCR en unos, y en otros el INL para diferentes momentos del perioperatorio en relación a diferentes técnicas anestésicas empleadas. 
Según refiere Martínez HY (2016), en su tesis para optar al título de especialista en anestesiología, en la Universidad Nacional Autónoma de México, existe relación de incremento entre el índice neutrófilos/linfocitos de las pacientes sometidas a mastectomía radical con anestesia general balanceada. Sus resultados son consecuentes con los nuestros en razón a que la anestesia general con agentes inhalados y opioides se ve que guarda relación directamente proporcional al incremento de los valores del INL, pero hay sesgos intragrupales en su estudio, al incluir pacientes que han recibido transfusiones sanguíneas, drogas inmunosupresoras tanto previos como posteriores al tratamiento quirúrgico, y es conocido que estos son factores independientes que alteran muy significativamente la respuesta inmune del organismo.

De forma tal que partiremos de nuestro primer objetivo, y en cuanto a la caracterización del grupo A y el $\mathrm{B}$, ambos no tuvieron diferencias estadísticamente significativas en cuanto a las variables demográficas. Los valores pre operatorios de PCR fueron de 0.79 y 0.75 respectivamente para los grupos A y $\mathrm{B}$, no siendo diferentes estadísticamente con una p valor de 0.77 , por lo que son consideradas las medias iguales. Y para el valor pre operatorio del INL tenemos 2.86 para ambos grupos A y B, con una $\mathrm{p}$ valor de 0.98 , aceptando la hipótesis nula de igualdad de las medias.

En cuanto al segundo objetivo, en relación a los valores de PCR a las 48 horas tenemos una relación estadísticamente significativa entre obtener valores mayores en los que recibieron anestesia general inhalatoria pertenecientes al grupo A en comparación al grupo B, que recibió AMELO y tuvo valores muy bajos.

Si vemos la relación de la técnica anestésica empleada con la variación de los valores que tenían en el preoperatorio a los que luego se identificaron en el postoperatorio, para ambas variables (PCR e INL); ambas experimentaron un aumento y en ambos grupos estudiados, siendo el aumento sobre los valores basales estadísticamente significativo se puede inferir que cualquiera de las técnicas anestésicas empleadas no evitan el aumento de los valores respectivos, lo cual es una evidencia de la respuesta del organismo ante la agresión quirúrgica; el punto de observación está en cuál técnica anestésica de las estudiadas logra mejor modulación de ambas respuestas. Y se encuentra hasta el momento que para el grupo control, tanto los valores de PCR como los de INL son superiores en las 48 horas tras la intervención en comparación con los valores del grupo B. Por lo que los resultados de este estudio guardan relación con lo que sostiene en sus estudios Hans Jorge Nielsen (2000) en el cual sostiene que no solo guarda relación con la técnica 
anestésica empleada los valores obtenidos en el post operatorio, sino que también se relaciona con el estadio tumoral, y otras variables independientes tales como el haber recibido transfusiones sanguíneas.

Así mismo, Nora María Moselli (2011) sostiene en su estudio que la analgesia epidural intraoperatoria previene la pronta respuesta pro-inflamatoria secundaria al trauma quirúrgico. Y en lo que respecta a las variables de medición empleada se hizo valer en su estudio de mediciones de varias interleuquinas, en cambio el actual estudio lo hizo obteniendo los valores de PCR e INL.

En relación al tercer objetivo, la determinación de puntos de corte óptimos para evaluar a una técnica anestésica en su objetivo de lograr una mejor modulación de la respuesta ante el trauma quirúrgico, es evidente que el punto de corte estimado para la PCR resulta de gran utilidad y es equiparable a lo que para otros estudios es estimado en valores similares a 2 y 2.4 respectivamente, según Mirellis (2011) y Velázquez (2015), en tales estudios estos valores fueron el corte para estimar la relación con complicaciones en el postoperatorio, de pacientes con cáncer de colon, recto y próstata respectivamente. No sucede lo mismo para el valor de corte estimado de INL, el cual no demuestra diferencias estadísticamente significativas entre ambos grupos, pero si hay mejor respuesta inmune en el grupo experimental con bajos niveles de INL en comparación al grupo control, y la diferencia resulta significativa. Estos resultados guardan relación con lo que sostiene Jun Zhu (2017) en su estudio "Effects of combined epidural and general anesthesia on intraoperative hemodynamic responses, postoperative cellular immunity, and prognosis in patients with gallbladder cancer" en dónde provee evidencia que la anestesia general combinada con analgesia epidural provee mejores resultados y óptimos de la respuesta inmune celular.

Los objetivos 4 y 5 guardan relación con el análisis y la discusión realizada y se complementan en el orden estadístico, siendo planteados para apoyar la evaluación final de la respuesta inflamatoria e inmune en relación a la técnica anestésica empleada. Es por ello que el autor emite juicio propio a favor del empleo de la técnica AMELO gracias a la mejor modulación de la inflamación y del sistema inmune tras la injuria quirúrgica.

Finalmente, en cuanto al comportamiento de las variables hemodinámicas durante el intraoperatorio y los eventos adversos de hipo e hipertensión arterial, y en cuanto a la necesidad de rescate analgésico intraoperatorio para las dos técnicas anestésicas evaluadas en el presente estudio, estos resultados son consistentes con los obtenidos por 
Jun Zhu (2017) igualmente. Según Zhu, dónde compara la anestesia general inhalatoria con sevorane más remifentanil frente a la general endovenosa con midazolam, remifentanil y analgesia epidural, en su estudio se obtiene mejor atenuación de los cambios hemodinámicos intraoperatorios, menos eventos de hipertensión arterial y mayor estabilidad de la presión arterial y la frecuencia cardíaca, siendo las medias similares a las obtenidas en el estudio actual. Pero en lo que no concuerda el estudio de estos autores con el presente, es que para el grupo que recibió analgesia epidural se mantuvo la anestesia también con remifentanil en infusión, y el anestésico local empleado fue la levobupivacaina.

\section{REFERENCIAS BIBLIOGRÁFICAS}

Albrecht E, Kirkham KR, Liu SS, Brull R. Peri-operative intravenous administration of magnesium sulphate and postoperative pain: a meta-analysis. Anaesthesia 2013;68(1):79e90.

Álvarez-Vega J. ¿Cómo evaluar la respuesta infl amatoria postoperatoria? Rev Mex Anest 2014: Vol 37, Sup 1, p S23

Antoni MH, Lutgendorf SK, Cole SW, Dhabhar FS, Sephton SE, McDonald PG, et al. The influence of bio-behavioural factors on tumour biology: pathways and mechanisms. Nat Rev Cancer 2006;6(3):240-8.

Anuario de Mortalidad de la República Bolivariana de Venezuela 2013. Recuperado a partir de: http://www.ovsalud.org/publicaciones/documentos-oficiales/anuariomortalidad-2013/

Aristomenis K, et al. Can anesthetic technique for primary breast cancer surgery affect recurrence or metastasis?. Anesthesiology. 2006 October ; 105(4): 660-664.

Bajwa SJ, Anand S, Kaur G. Anesthesia and cancer recurrences: the current knowledge and evidence. J Cancer Res Ther 2015; 11:528-534.

Baumann H, Gauldie J. The acute phase response. Immunol Today. 1994;15(2):74-80.

Beilin B, Shavit Y, Hart J, Mordashov B, Cohn S, Notti I, et al. Effects of anesthesia based on large versus small doses of fentanyl on natural killer cell cytotoxicity in the perioperative period. Anesth Analg 1996;82(3):492-7. 
Ben-Eliyahu S, Page GG, Yirmiya R, Shakhar G. Evidence that stress and surgical interventions promote tumor development by suppressing natural killer cell activity. Int J Cancer 1999; 80: 880-8.

Biki B, Mascha E, Moriarty, Fitzpatrick JM, Sessler DI, Buggy DJ. Anesthetic technique for radical prostatectomy surgery affects cancer recurrence: A retrospective analysis. Anesthesiology 2008;109:180-7.

Bovill J. Surgery for cancer: does anesthesia matter? Anesth Analg 2010;110(6):1524-5.

Brain Behav Immun 2012. Advance access published on 4 April 2012. PMID: 22504092.

Brand JM, Kirchner H, Poppe C, Schmucker P. The effects of general anesthesia on human peripheral immune cell distribution and cytokine production. Clin Immunol Immunopathol 1997;83(2): 190-4.

Buggy DJ, Smith G. Epidural anaesthesia and analgesia: Better outcome after major surgery? Growing evidence suggests so. BMJ 1999;319:530-41.

Chang EI, Zárate MA, Rabaglino MB, Richards EM, ArndtTJ, Keller-Wood M, et al. Ketamine decreases inflammatoryand immune pathways after transient hypoxia in late gesta-tion fetal cerebral cortex. Physiol Rep. 2016:4, pii: e12741

Clemenceau VP. Anestesia y recurrencia. Rev Mex Anest. 2015;38: S314-S317.

Clinical anesthesiology. Morgan GE. Ed. Appleton \& Lange. 2a ed. 1996.

Corcoran TB, Engel A, Sakamoto H, O'Shea A, O'Callaghan-Enright S, Shorten GD. The effects of propofol on neutrophilfunction, lipid peroxidation and inflammatory response duringelective coronary artery bypass grafting in patients with impai-red ventricular function. Br J Anaesth. 2006;97:825---31.15

Dale O, Somogyi AA, Li Y, Sullivan T, Shavit Y. Does intraoperative ketamine attenuate inflammatory reactivity following surgery? A systematic review and meta-analysis. Anesth Analg 2012;115(4):934e43.

De Kock M, Loix S, Lavand'homme P. Ketamine and peripheralinflammation. CNS Neurosci Ther. 2013;19:403---10

Elena G, Acosta AP, Antoniazzi S, Tettamanti V, Méndez F, Colucci D et al. Estudio comparativo de anestesia total intravenosa con midazolam-ketamina-fentanilo y remifentanilo-midazolam: evaluación de la respuesta hemodinámica, leucocitaria y 
de los marcadores sistémicos de estrés. Rev Esp Anestesiol Reanim. 2006;53(5):275-82.

Elkaradawy S, Nasr M, Elkerm Y, Deeb ME, Yassine O. The effect of multimodal balanced anaesthesia and long term gabapentin on neuropathic pain, nitric oxide and interleukin-1 $\beta$ following breast surgery. Egyptian Journal of Anaesthesia. $2012 ; 28: 67-78$

Exadaktylos AK, Buggy DJ, Moriarty DC, Mascha E, Daniel I, Sessler DI. Can anesthetic technique for primary breast cancer surgery affect recurrence or metastasis? Anesthesiology 2006;105(4):660-4.

Galley HF, Dubbels AM, Webster NR. The effect of midazolam and propofol on interleukin-8 from human polymorphonuclearleukocytes. Anesth Analg. $1998 ; 86: 1289---93$

Gottschalk A, Sharma S, Ford J, Durieux ME, Tiouririne M. Review article: the role of the perioperative period in recurrence after cancer surgery. Anesth Analg 2010; 110: $1636-43$.

Graziola E, Elena G, Gobbo M, Méndez F, Colucci, Puig N. Estudio sobre la respuesta al estrés, hemodinámica e inmunológica de dos técnicas anestésicas (inhalatoria e intravenosa) en colecistectomías videolaparoscópicas. Rev Esp Anestesiol Reanim. 2005;52(4):208-16.

Hans Nielsen, Jarle Christensen, Steen Sørensen, Flemming Moesgaard, Nils Brunner, et al. Preoperative Plasma Plasminogen Activator Inhibitor Type-1 and Serum CReactive Protein Levels in Patients With Colorectal Cancer. Annals of Surgical Oncology 2000. Vol: 7(8):617-623

Hattori M, Dohi S, Nozaki M, Niwa M, Shimonaka H. The inhibitory effects of local anesthetics on superoxide generation of neutrophils correlate with their partition coeffi cients. Anesth Analg [Internet]. 1997 [citado 19 de agosto de 2014];84:405412. Available from: http://www.ncbi.nlm.nih.gov/pubmed/9024038

Jun Zhu, Xue-Rong, Hu Yang. Effects of combined epidural and general anesthesia on intraoperative hemodynamic responses, postoperative cellular immunity, and prognosis in patients with gallbladder cancer. A randomized controlled trial. Rev Medicine (2017) 96:10 
Koltai T. Voltage-gated sodium channel as a target for metastatic risk reduction with repurposed drugs. F1000Res. 2015;4:297.

Kurosawa. Anesthesia in patients with cancer disorders. Curr Opin Anesthesiol. 2012;25:376-384.

Kushida A, Inada T, Shingu K. Enhancement of antitumor immunity after propofol treatment in mice. Immunopharmacol Immunotoxicol 2007; 29:477-86.

Lennard TW, Shenton BK, Borzotta A, Donnelly PK, White M, Gerrie LM, et al. The influence of surgical operations on components of the human immune system. Br J Surg 1985;72(10):771e6.

Lirk P, Berger R, Hollmann MW, Fiegl H. Lidocaine time- and dose-dependently demethylates deoxyribonucleic acid in breast cancer cell lines in vitro. Br J Anaesth. 2012;109(2):200-207.

Longas J, Guerrero LM, Gonzalo A, Infantes M, Rodríguez A, Abengoechea JM. Estudio comparativo de cuatro técnicas de anestesia general en endarterectomía carotídea: respuesta inflamatoria, complicaciones cardiocirculatorias y analgesia postoperatoria. Rev Esp Anestesiol Reanim. 2004;51(10):568-75.

Looney M, Doran P, Buggy DJ. Effect of anesthetic technique on serum vascular endothelial growth factor $\mathrm{C}$ and transforming growth factor in women undergoing anesthesia and surgery for breast cancer. Anesthesiology 2010;113:1118-25.

Mathy-Hartert M, Deby-Dupont G, Hans P, Deby C, LamyM. Protective activity of propofol, Diprivan and intralipidagainst active oxygen species. Mediators Inflamm. $1998 ; 7: 327---33$

Mayo NE, Feldman L, Scott S, Zavorsky G, Kim DJ, Charlebois P, et al. Impact of preoperative change in physical function on postoperative recovery: Argument supporting prehabilitation for colorectal surgery. Surgery. 2011; 150:505-514.

Melamed R, Bar-Yosef S, Shakhar G, Shakhar K, Ben-Eliyahu S. Suppression of natural killer cell activity and promotion of tumor metastasis by ketamine, thiopental, and halothane, but not by propofol: mediating mechanisms and prophylactic measures. Anesth Analg. 2003;97(5):1331-1339. 
Mille-Loera JE, Cuellar Guzmán LF, Alvarado Pérez J, García-Velasco O, FabelaBarragán JA. Consideraciones anestésicas en el paciente con cáncer. Rev Mex Anest. Vol. 40. Supl. 1 Abril-Junio 2017. pp S132-S134.

Miranda-Rangel A, Martínez-Segura T. Anestesia multimodal: una visión de la anestesia moderna. Rev Mex Anest 2015: Vol 38, Sup 1, pp S300-S301

Mulier JP, Dhaese H, Van Lancker P. Non-opiate surgical anesthesia. A paradigm shift? UZ Gent lecture. 2013.

Neeman E, Ben-Eliyahu S. Surgery and stress promote cancer metastasis: new outlooks on perioperative mediating mechanisms Effect of anaesthetic and analgesic techniques on cancer recurrence or metastasis and immune involvement.

Nora Maria M, Baricocchi E, Ribero D, Sottile A, Suita L, Debernardi F. Intraoperative Epidural Analgesia Prevents the Early Proinflammatory Response to Surgical Trauma. Results from a Prospective Randomized Clinical Trial of Intraoperative Epidural Versus General Analgesia. Ann Surg Oncol (2011) 18:2722-2731-34.

Page GG, Blakely WP, Ben-Eliyahu S. Evidence that postoperative pain is a mediator of the tumor-promoting effects of surgery in rats. Pain 2001;90:191-9.

Page GG, Blakely WP, Ben-Eliyahu S. Evidence that postoperative pain is a mediator of the tumor-promoting effects of surgery in rats. Pain 2001;90:191-9.

Palomero RMA, Cacharro MLM, Mollinedo F. Inflamación, cáncer y ¿anestesia? Rev Esp Anestesiol Reanim. 2008; 55:135-136.

Proctor MJ, Morrison DS, Tallwar D, Balmer SM, O’Reilly DSJ, Foulis AK, et al. An infl ammation-based prognostic score (mGPS) predicts canccer survival independent of tumor site: a Glasgow Infl ammation Outcome Study. British Journal of Cancer. 2011;104:726-734.

Reynoso NN, Mohar BA. Epidemiología del cáncer. En: Herrera GA, Ñamendys SSA, Meneses GA. Manual de Oncología procedimientos médico quirúrgicos. Cap. 2, Sexta edición. McGrawHill. 2017; pp. 10-18.

Rodés J, Trilla A, Carné X. Terapéutica médica. Capítulo anestesia y analgesia. Ed. Masson. $1^{\text {a }}$ ed. 2002 
Sacerdote P, Bianchi M, Gaspani L, Manfredi B, Maucione A, Terno G, et al. The effects of tramadol and morphine on immune responses and pain after surgery in cancer patients. Anesth Analg 2000; 90(6):1411-4.

Schulz-Stübner S, Sinner B, Becke K, Engelhard K, Guay J, Choi PT, et al. Multimodal anesthesia and systems neuroscience: the new frontier. Anesthesiology. 2008;109:948-950

Shakhar G, Ben-Eliyahu S. Potential prophylactic measures against postoperative immunosuppression: Could they reduce recurrence rates in oncological patients? Ann Surg Oncol 2003;10:972-92.

Shakhar G, Ben-Eliyahu S. Potential prophylactic measures against postoperative immunosuppression: could they reduce recurrence rates in oncological patients? Ann Surg Oncol 2003;10(8):972-92.

Szpunar MJ, Burke KA, Dawes RP, Brown EB, Madden KS. The antidepressant desipramine and alpha2-adrenergic receptor activation promote breast tumor progression in association with altered collagen structure. Cancer Prev Res (Phila). 2013;6(12):1262-1272.

Talmadge JE, Fidler IJ. AACR centennial series: the biology of cancer metastasis: historical perspective. Cancer Res 2010; 70: 5649-69.

Vargas-Hernández J. Anestesia libre de opioides. Rev Mex Anest 2014: Vol 37, Sup 1, pp S24-S27

Wada H. Combined spinal and general anesthesia attenuates liver metastasis by preserving TH1/TH2 cytokine balance. Anesthesiology. 2007;106(3):499-506

Welters ID, Feurer MK, Preiss V, Müller M, Scholz S, Kwa-pisz M, et al. Continuous S$(+)$-ketamine administration duringelective coronary artery bypass graft surgery attenuatespro-inflammatory cytokine response during and after cardiopul-monary bypass. Br J Anaesth. 2011;106:172---9

Xia Z, Huang Z, Ansley DM. Large-dose propofol during cardio-pulmonary bypass decreases biochemical markers of myocardial injury in coronary surgery patients: A comparison with isofluorane. Anesth Analg. 2006;103:527---32

Zahorec R. Ratio of neutrophil to lymphocyte counts- rapid and simple parameter of systemic inflammation and stress in critically ill. Bratisl Lek Listy 2001;102:5-14. 
Zetter BR. Angiogenesis and tumor metastasis. Anu Rev Med 1998;49:407-24.

\section{Anexos}

\section{Gráfico 1: Valores de PCR e INL a las 48 del post-operatorio} 99\% IC de Bonferroni para la media
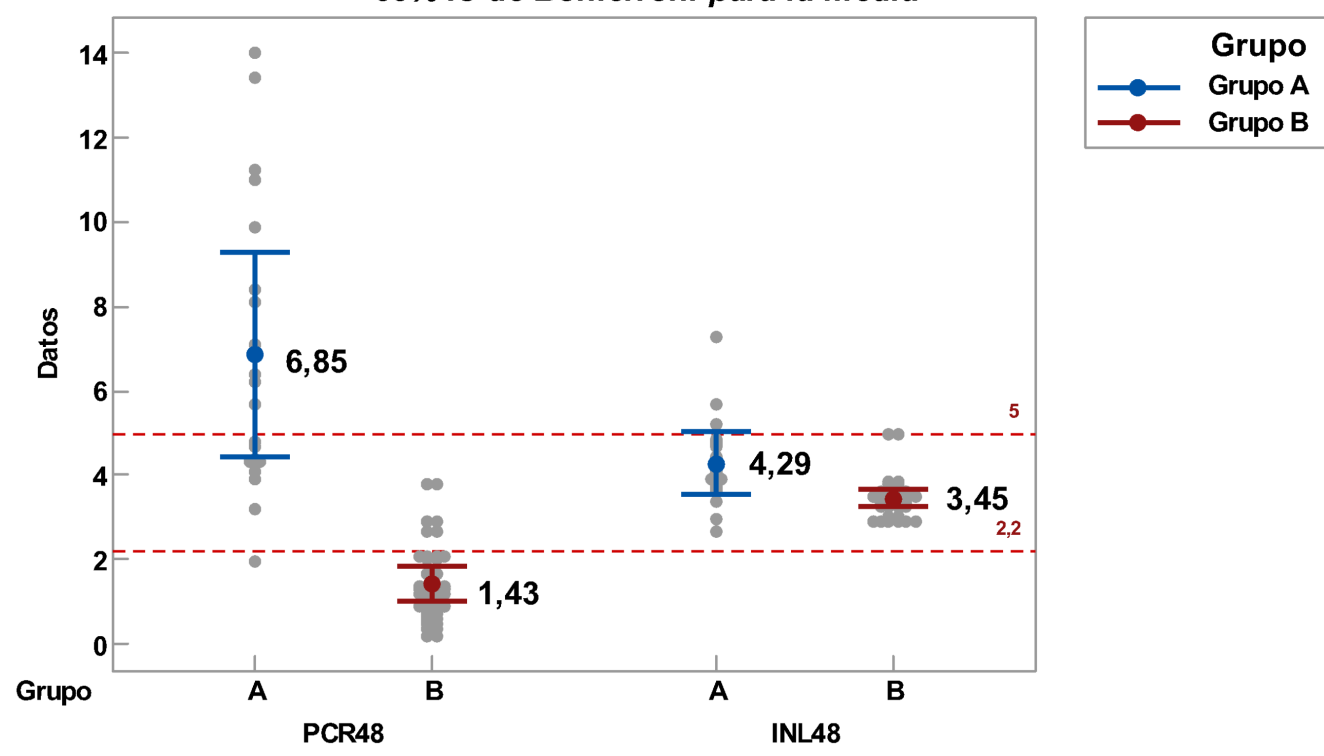

Líneas de corte en eje Y 2.2 para la PCR y de 5 para el INL
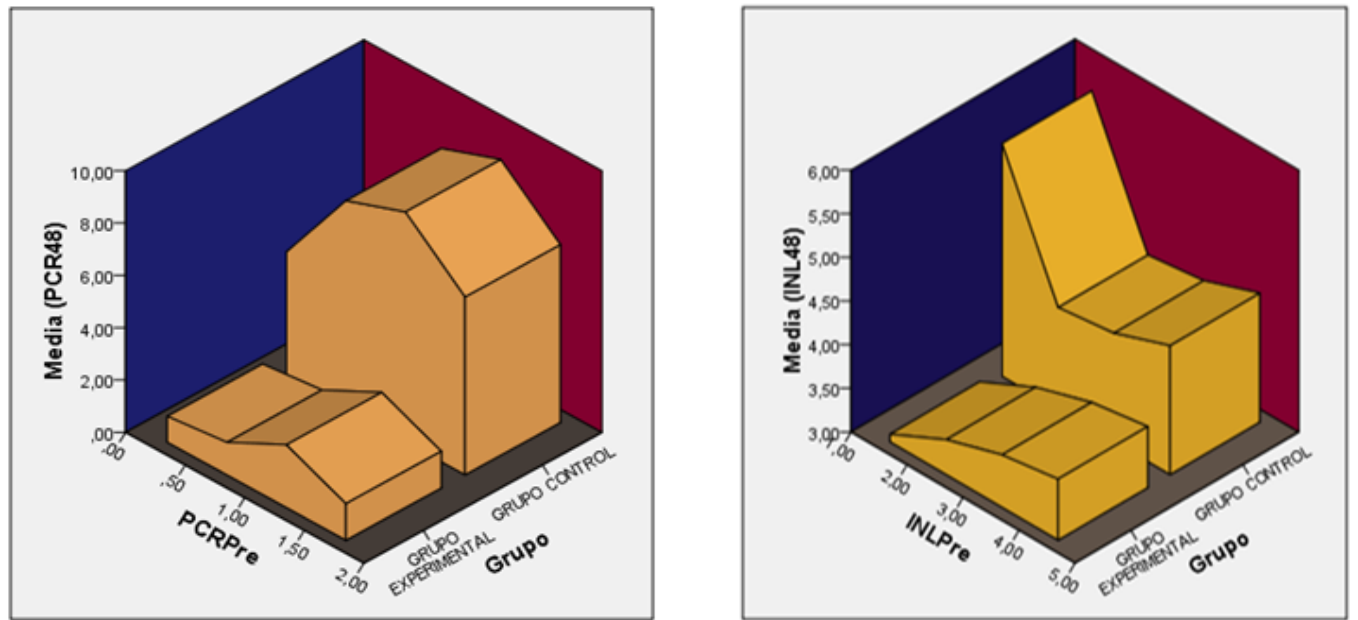
Presión arterial media por grupos de estudio durante el intra-operatorio
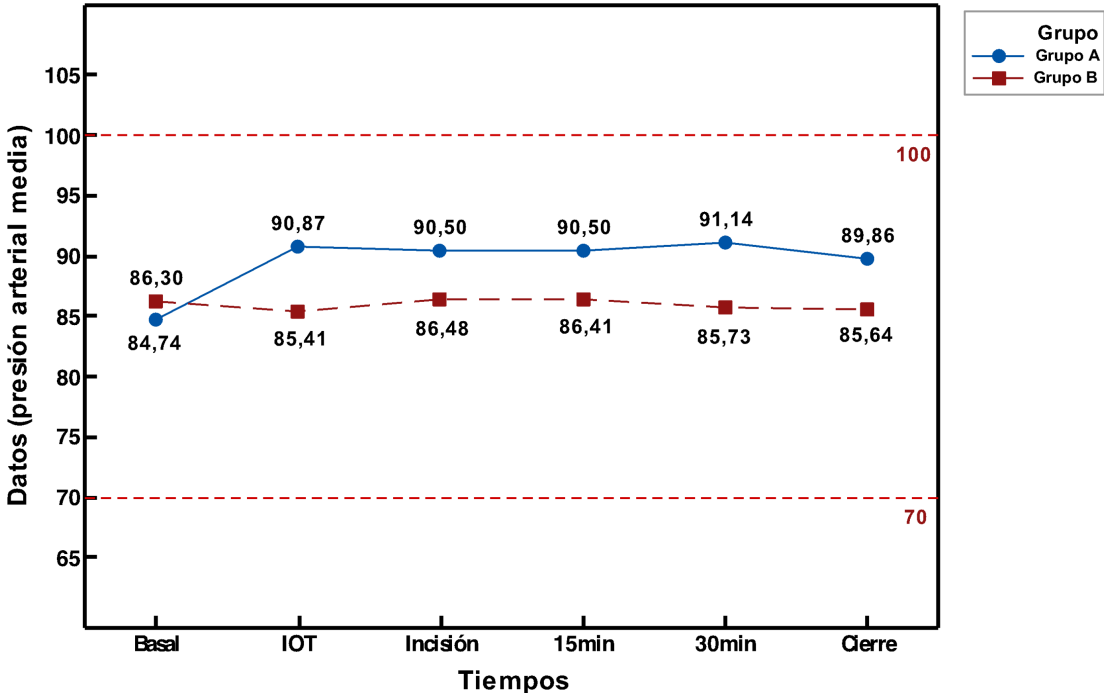

Gráfico 2: Odds Ratio para relación entre técnicas anestésicas y aumento sobre valores de los puntos de corte para la PCR y el INL

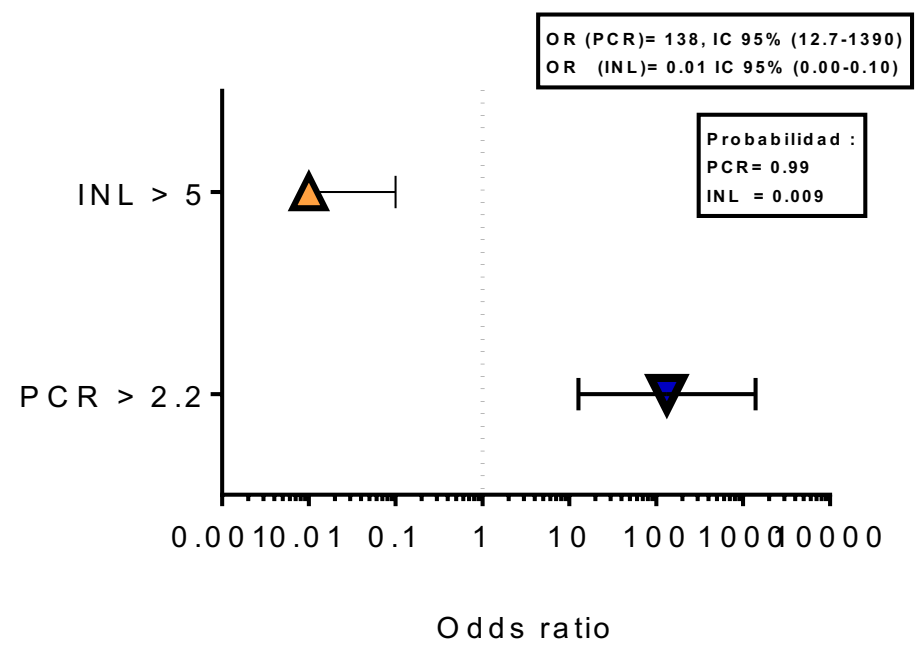

\section{Gráfico 3:}

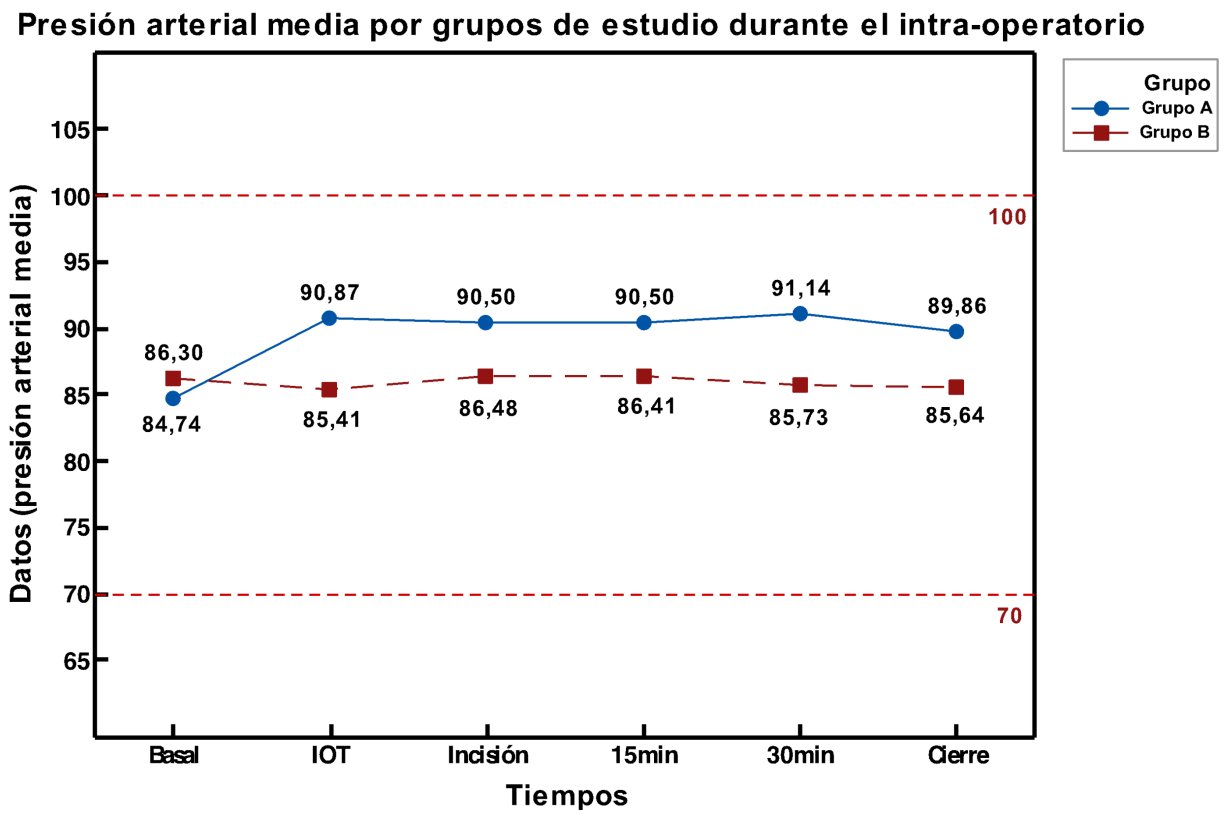




\section{Gráfico 4:}

Frecuencias cardiacas medias por grupos de estudio durante el intra-operatorio
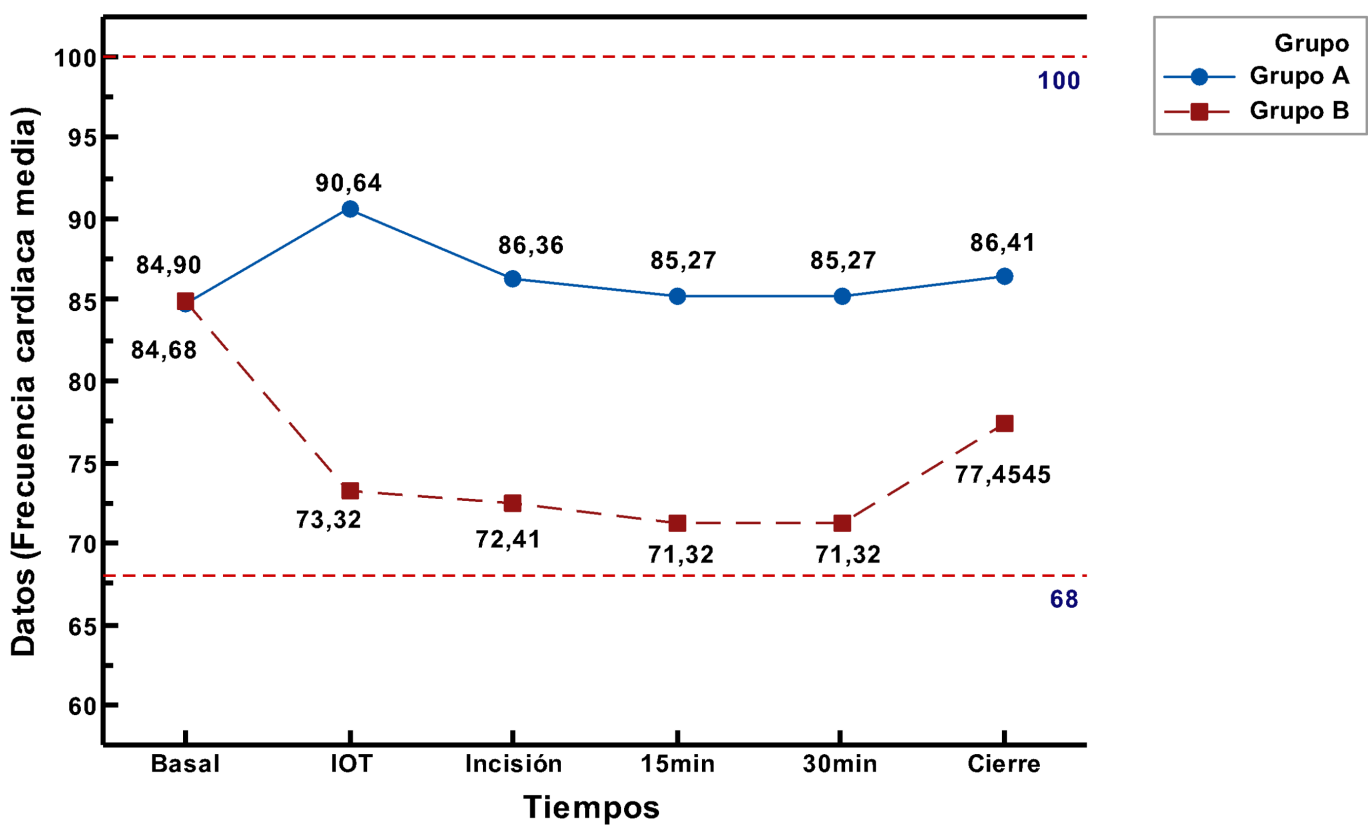

Pelean ahora esto es lo que va a pasar

Gráfico 5: Odds Ratio relaciones entre técnicas anestésicas vs PCR, INL, eventos de hipotensión arterial, eventos de hipertensión arterial y necesidad de rescate analgésico.

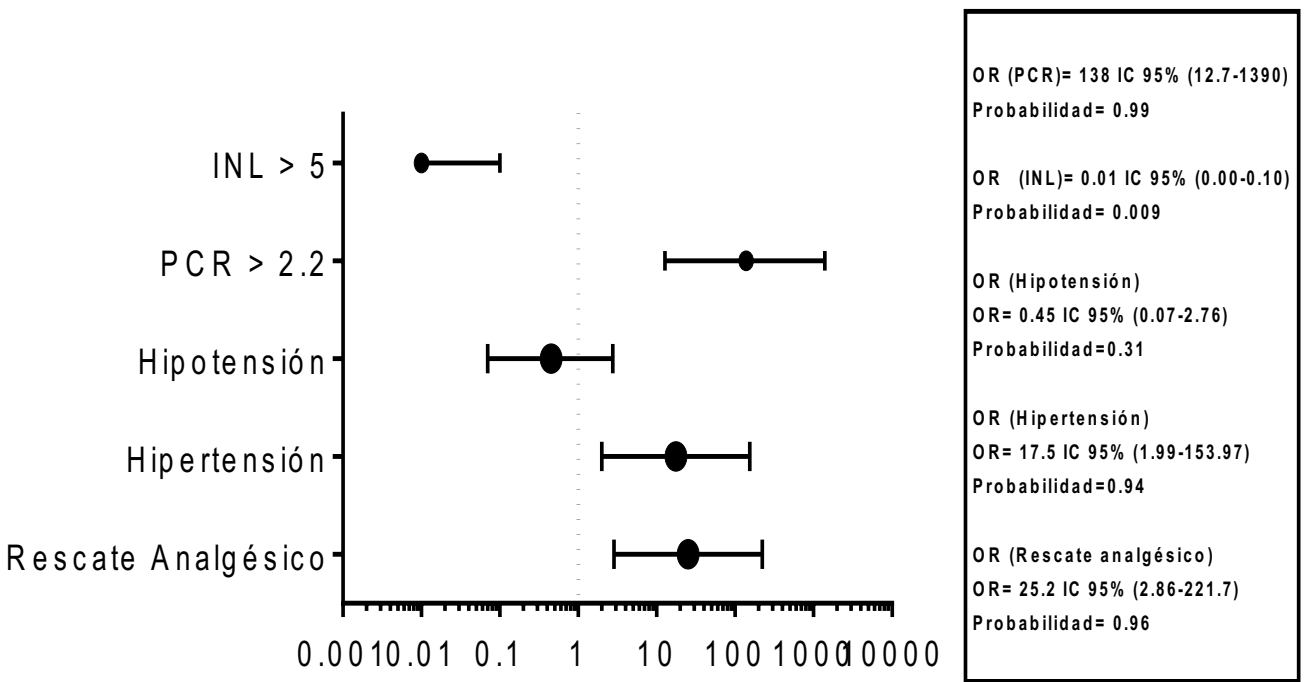

Odds ratio 


\section{Gráfico 6:}

Dolor según EVA durante las primeras 24 horas tras la cirugía

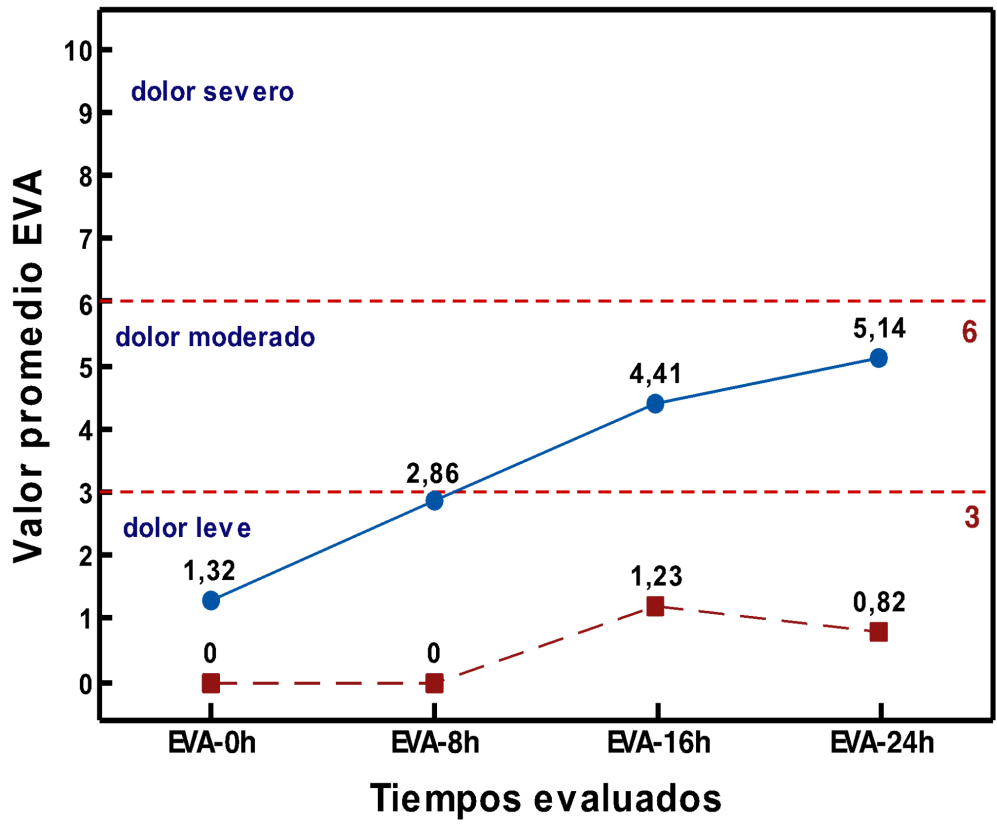

